\title{
Leverage and Growth Opportunities: Risk-A voidance Induced by Risky Debt
}

\author{
José A Imeida Brito \\ (Universidade Católica Portuguesa)
}

\author{
and \\ Kose John \\ (New York University)
}

José Almeida e Brito

Universidade Católica Portuguesa

Faculdade de Ciências Económicas e Empresariais

Palma de Cima, 1600 Lisboa, Portugal Tel:351-217 214254 Fax:351-217 270252

E-mail: gbrito@fcee.ucp.pt
Kose John New York University Stern School of Business 44 West Fourth Street, Suite 9-190 New York, N. Y. 10012-1126, USA Tel: (212) 998-0337. Fax: (212) 995-4233

E-mail: kjohn@stern.nyu.edu 


\title{
Leverage and G rowth 0 pportunities: Risk-A voidance Induced by Risky D ebt*
}

\begin{abstract}
A bstract
This paper shows that illiquid growth opportunities crucially impact the agency costs of risky debt. If the value of these growth opportunities is sufficiently high, they reverse riskshifting incentives into risk-avoidance incentives, creating a new agency cost of debt. They can also el iminate Myers's underinvestment problem.

It is widely accepted in Corporate Finance that risky debt induces incentives for risk-shifting by the residual equityholder. This paper shows that this result is subject to important qualifications: risky debt does not necessarily create risk-shifting incentives. For a relevant subset of firms it creates instead the opposite effect: it induces risk-avoidance behavior. With risky debt outstanding, the shareholders of a firm with illiquid growth opportunities may optimally prefer safer, less valuable projects to riskier projects with higher net present values. These shareholders present risk-avoidance behavior to preserve control of the firm and to appropriate the firm's future economic rents. The paper models the firm's risk choices in a framework that shows the ex-post optimality of both risk-avoidance and risk-shifting behavior. The presence of illiquid growth opportunities extends the maturity of the equity contract beyond the maturity of the debt contract, explicitly accounting for the nature of the firm as a going concern. The paper constitutes a contribution towards a multiperiod perspective in Corporate Finance, while retaining the parsimony and elegance of finiteperiod settings.
\end{abstract}

JEL Classification codes: G32, G30

\footnotetext{
${ }^{*}$ We are very grateful to Fernando Branco, Sandeep Dahiya, Zsuzsanna Fluck, Jose Guedes, Anurag Gupta, S. Abraham Ravid, Alexander Reisz, Marti Subrahmanyam and David Yermack for their comments and suggestions. The usual disclaimer applies.
} 


\subsection{Introduction}

According to received theory in Corporate Finance, risky debt creates an incentive for excessive risk-taking on the part of the firm (Jensen and Meckling, 1976; Green, 1984). Yet in practice, business journals frequently document instances of conservatism associated with risky debt, such as the investment policies of leverage buy-out firms. These highly leveraged firms usually pursue divestitures, asset sales and an increase in focus on their main business, presenting an investment policy which decreases, instead of increasing, their business risk. This paper reanalyzes traditional risk-shifting and underinvestment incentives in a simple setting where the firm has outstanding some illiquid growth opportunities. The presence of illiquid growth opportunities extends the maturity of the equity contract beyond that of the debt contract (Fluck, 1998). The paper shows that these growth opportunities have a crucial impact on the agency costs of risky debt: they can eliminate Myers' underinvestment problem and reverse risk-shifting incentives into risk-avoidance behavior.

In addition to explaining why highly levered firms might exhibit conservative investment policies, the results developed in this paper also contribute to understanding why young firms in technology driven sectors avoid issuing debt. These firms have future growth opportunities, which can, potentially, be very high and which need to be pursued through risky investment policies. A sa result they usual ly face uncertainty concerning the timing and the level of their initial cash-flows. If these firms were financed with debt, their owners would risk losing control of the firm before realizing its economic potential. Or, instead, to preserve control of the firm, they would pursue a more conservative investment policy, which, in turn, could compromise the full realization of their growth opportunities. In the terminology introduced in this paper, these firms avoid debt financing because debt would create severe risk-avoidance incentives.

Consider an entrepreneur who must choose between two mutually exclusive projects: one is risky, another is safe. How will she choose? If the firm is all-equity financed, she will choose the project with the highest net present value. If the firm has risky debt outstanding, the received theory tells us that she might prefer the riskier project even if it has a lower, 
potentially negative, net present value: she faces risk-shifting incentives (Jensen and Meckling, 1976; Green, 1984). This paper shows that if the firm has illiquid growth opportunities, the entrepreneur might actually prefer the safer project to the riskier project, even if the safer project has a lower net present value. The entrepreneur faces risk-avoidance incentives, which create what is, to the best of our knowledge, a new agency cost of risky debt.

The risk-shifting incentives created by risky debt constitute a major tenet of Corporate Finance theory:

"With that financial structure (firms financed almost entirely with debt type claims) the owner-manager will have a strong incentive to engage in activities (investments) which promise very high payoffs if successful even if they have a very low probability of success. If they turn out well, he captures most of the gains, if they turn out badly, the creditors bear most of the costs" (Jensen and Meckling, 1976, pg. 334).

Risk-shifting incentives create an agency cost of risky debt, which has had an enormous impact both on the Corporate Finance literature (see, e.g., John and John, 1993; John and Nachman, 1985; Rajan, 1992) and on the teaching of Finance. ${ }^{1}$ This paper shows that risky debt does not always generate risk-shifting incentives; in many instances it will create, instead, the opposite incentives. The impact of risky debt on the firm's risk choices depends on the value of the firm's future investment opportunities. If the firm has illiquid growth opportunities, stockholders of levered firms might lose when business risk is increased. These stockholders will favor safer projects over riskier ones.

Risk-shifting problems have traditionally been studied in finite period models: "after timeT the firm has no productive activities so the payoff $X_{j}$ includes the distribution of all remaining assets" (Jensen and Meckling, 1976, pg. 335). The early papers explicitly stated

\footnotetext{
${ }^{1}$ The following quote constitutes a representative example: "The (previous) game illustrates the following general point: stockholders of levered firms gain when business risk increases. Financial managers who act strictly in their shareholder's interest (and against the interests of creditors) will favor risky projects over safe ones. They may even take risky projects with negative NPVs" (Brealey and Myers, "Principles of Corporate Finance", 1996, pg. 492). This paper shows that this result is not general: for a relevant subset of levered firms, shareholders lose when business risk is increased.
} 
that the finite period approach created some limitations: "all dynamic aspects of the multiperiod nature of the problem are ignored by assuming there is only one productionfinancing decision to be made by the entrepreneur." (Jensen and Meckling, 1976, pg. 314); "our single-period discrete time framework limits the generality of the analysis" (Green, 1984, pg. 116). Jensen and Meckling even dedicated a sub-section of their paper to multiperiod aspects of the agency problem. They recognized that they had "ignored the issues associated with the incentives affecting future financing-investment decisions", that "these are important issues which are left for future analysis" and that they "will tend to reduce the size of the agency costs" (Jensen and Meckling, 1976, pg. 351).

Subsequent research has failed to address these multiperiod issues and the cautionary note explicitly present in the original papers has become much more implicit or even absent. This paper shows that Jensen and Meckling's cautionary notes were actually crucial: the traditional discrete time framework, in which the firm is not really a going concern, truly limits the generality of the results. We present a methodology which explicitly models the firm as a going concern, even at the model's terminal date, and still retains the parsimony and el egance of the traditional discrete time framework.

Fluck (1998) shows that a fundamental characteristic of the equity contract is that it has an indefinite maturity as opposed to the finitematurity of most debt contracts. Our paper shows that the fact that equity has a longer maturity than debt has crucial implications concerning the agency costs of debt. Our model extends the maturity of the equity contract beyond that of the debt contract and it shows that, as a result, risk-shifting incentives are always mitigated and will often be reversed. The shareholders of a firm with valuable illiquid growth opportunities will optimally present risk-avoidance behavior to preserve control of the firm and, consequently, to appropriate the val ue of the firm's future economic rents.

This paper is very close in spirit to the banking literature adopting the charter value perspective (se, e.g., Keeley, 1990; A charya, 1996). This literature is motivated by the question "Why do we not see highly levered banks, with insured deposits, taking on more risk?". A fixed-rate deposit insurance reinforces bank's incentives to risk-shift, but empirical research does not show banks generally trying to maximize the risk of their assets (Furlong and 
Keeley, 1987, 1989). The charter value literature argues that banks do not risk-shift as much as expected because they have valuable illiquid charters which the bank owners would lose in insolvency: " with valuable charters as assets, banks had an incentive not to risk failure since the owners of the banks cannot sell the charter once the bank is declared insolvent" (Keeley, 1990, pg. 1185). This literature then attempts to link the evolution of bank charter value with the levels of bankruptcy in banking: they argue that risk-shifting becomes an issue in banks only when their charter value decreases. This paper shares its basic intuition with the charter value perspective: risk-shifting incentives are mitigated by the presence of illiquid assets. This paper differs by, among other features, presenting a general model concerned with the firm's risk choices and the agency costs of debt, while the charter value literature is focused on banking regulation and the risk incentives of deposit insurance. ${ }^{2}$

In addition to the literature on risk-shifting incentives, this paper is also related to papers concerned with non-pecuniary bankruptcy costs (see, e.g., Diamond, 1984) and private benefits of control (see, e.g., Harris and Raviv, 1988, 1991; Diamond, 1991). The loss of the firm's illiquid growth opportunities represents a cost suffered in bankruptcy by shareholders, which is not ameliorated by limited liability. The same applies to non-pecuniary bankruptcy costs and to private benefits of control. They all represent different, cumulative sources of risk-avoidance behavior on the part of shareholders. Other related papers are those concerned with inefficient liquidation or liquidity risk (see, e.g., Diamond, 1991; Hart and Moore, 1989; Bolton and Scharfstein, 1990). The presence of illiquid growth opportunities can also generate inefficient liquidation. This paper differs from the previous papers because it is focused on the distortions introduced by the above features on the entrepreneur's investment policy. In particular, it is centered on the entrepreneur's risk choices and the resulting agency costs.

The remainder of this paper is organized as follows: section II develops the basic model which incorporates illiquid growth opportunities into the traditional risk-shifting finiteperiod model, section III discusses risk-shifting and risk-avoidance incentives in terms of

\footnotetext{
${ }^{2}$ After drafting this paper we have realized that Herring and Vankudre (1987) have developed a model, in the context of deposit insurance, banking regulation and risk taking behavior by banks, where the bank's assets are clearly separated into current assets $(A)$ and the value of growth opportunities, which they naturally called $G$. Although their model is different from ours, the modeling of the growth opportunities is similar in both models.
} 
option theory and section IV presents the impact of risk-avoidance incentives in the agency costs of debt. Section V shows the impact of illiquid growth opportunities in Myers' (1977) underinvestment and provides an integration of risk-shifting incentives, risk-avoidance incentives and Myers' underinvestment problem. We show that the nature of the riskavoidance problem - underinvestment in risky projects - is conceptual ly quite different from Myers' underinvestment. Section VI discusses the potential contributions of this paper concerning methodology and the paper's empirical implications and section VII concludes.

\subsection{The Model}

\subsubsection{The Traditional Risk-Shifting M odel}

The model is closely related to classic risk-shifting models (see, e.g., Jensen and Meckling, 1976; Green, 1984). The basic setup follows John and John (1993) and it is designed to highlight the crucial issues as simply as possible. To focus on the conflicts between equityholders and debtholders, we abstract away from the conflicts between management and owners and consider an entrepreneur who manages her own firm. The model is centered on the entrepreneur's risk choices, which are presented as a choice between a risky project and a safe project. Our focus is the agency problem resulting from the entrepreneur's private information concerning the quality of the risky project. The asymmetry of information creates a problem of incomplete contracting in relation to the entrepreneur's risk choices.

The model has three dates. At date 0 the financial claims are issued and external investors pay, in a rational expectations framework, theappropriateprice for theseclaims. Weassume, in particular, that the firm issues a debt claim, as we are interested in studying the effects of risky debt on the firm's investment policy. The debt has a zero coupon, a face value of $F$ and matures at date 2 . All agents are risk neutral and the riskless interest rate is 0.

At date 1 the entrepreneur invests in one of two mutually exclusive investment projects: a risky project, $A$, or a riskless project, $B$. Both projects require an investment of $\mathrm{I}$. The riskless 
project has a zero net present value: it pays, at date 2, a cash-flow I with certainty. The risky project offers an uncertain pay-off: at date 2 it pays a high $(\mathrm{H})$ cash-flow with probability $p$, and a low ( $\mathrm{L}$ ) cash-flow with probability 1-p (by assumption $\mathrm{H}>\mathrm{I}>\mathrm{L}>0$ ). The net present value of the risky project is equal, at date 1 , to: $-I+p H+(1-p) L$.

The probability $p$ defines the quality of the risky project: the higher $p$ the higher the net present value of the risky project. At date 0 it is common knowledge, that $p$ is uniformly distributed over the interval $[0,1]$. At date 1 the entrepreneur sees $p$, which is private information, and, based on $p$, decides whether to invest in the risky project or in the riskless project. The agency problem arises because the quality of the risky project, $p$, is privately observed by the entrepreneur and is not verifiable. This implies that contracts contingent on $p$ cannot be enforced. At date 2 the final cash-flows are realized, the debt claim is paid and the residual amount accrues to the entrepreneur. Figure 1 gives a visual interpretation of this model.

To maximizeher own wealth theentrepreneur will makethefollowing investment decisions. If the firm is all-equity financed, the entrepreneur will invest in the project with the highest expected net present value. She will invest in the risky project A only if $p H+(1-p) L \geq I$. This is equival ent to investing in the risky project $A$ for all values of $p$ such that:

$$
p \geq p^{o}=\frac{I-L}{H-L}
$$

The entrepreneur's investment decision is defined by a cut-off level, p*. If the entrepreneur sees a value $p$ higher than the cut-off level, she chooses the risky project. If she sees a value $p$ lower than the cut-off level, she chooses the riskless project. The cut-off level, p*, characterizes the entrepreneur's risk choices: the lower the cut-off level the riskier the firm's investment policy as expressed in Lemma 1. All proofs are in the A ppendix.

Lemma 1: For $p_{1}<p_{2} \leq p^{O}$ the investment policy with a cut-off level $p_{1}$ generates a cash-flow distribution which is dominated, in terms of second order stochastic domination, by the cash-flow 
distribution associated with $p_{2}$. The investment policy with a cut-off level $p_{1}$ is then defined as being " riskier" than the investment policy with a cut-off level $p_{2}$.

If the firm has risky debt outstanding with repayment value $F(I>F>L)$, the entrepreneur will invest in the risky project if the expected cash-flows she receives from the risky project are higher than the certain cash-flow associated with the riskless project. She will invest in the risky project $A$ only if: ${ }^{3}$

$$
p[H-F]^{+}+(1-p)[L-F]^{+} \geq[I-F]^{+}
$$

For $\mathrm{I}>\mathrm{F}>\mathrm{L}$ this is equivalent to $p(H-F) \geq I-F$. The entrepreneur will then invest in the risky project $A$ for all values of $p$ such that:

$$
p \geq p^{F}=\frac{I-F}{H-F}
$$

The main result of traditional risk-shifting models is the following: as $p^{F}<p^{O}$, which results from $F>L$, there is overinvestment in the risky project which means there is riskshifting. Due to the presence of risky debt, the entrepreneur has incentives ex-post, at time 1 , to adopt an investment rule which deviates from the one that maximizes the firm value: she will invest too often in the risky project. In particular, she will invest in the risky project for all values of $p$ such that $p^{F} \leq p<p^{O}$, values for which the risky project has a negative net present value. This deviation from the optimal investment policy represents an agency cost of risky debt.

In a rational expectations equilibrium, the debtholders will correctly price ex-ante, at time 0 , the entrepreneur's ex-post incentives to deviate from the optimal investment policy. In consequence, the entrepreneur bears the agency costs of risky debt.

\footnotetext{
${ }^{3}$ By convention: $[\phi]^{+} \equiv \max [0, \phi]$.
} 


\subsubsection{Risk-Shifting Incentives with G rowth Opportunities}

This paper extends the above model by representing the firm as a going concern, even at the model's terminal date. This effectively extends the maturity of the equity contract beyond time 2. At every moment, including at time 2, the value of the firm is the sum of the value of assets-in-place and the value of future growth opportunities. At date 1 the entrepreneur sees the probability $p$ and the value of the growth opportunities, $G$, as private information. Both remain private information as of date 2 . As a consequence, at date 2 , the firm has some illiquid growth opportunities in addition to the terminal cash-flows. The growth opportunities will be exploited by the entrepreneur if she retains control of the firm at date2; they will belost if the entrepreneur does not retain control of the firm. ${ }^{4}$ For greater generality the model al lows for different values of growth opportunities $\left(G_{H}, G_{L}\right.$ and $\left.G_{I}\right)$ to beassociated with different states of nature.5,6 Figure 2 depicts the extension of the basic model to incorporate the future growth opportunities.

To maximize her own wealth the entrepreneur will now make the following investment decisions. In an all-equity firm she will invest in the project with the highest expected net present value. She will invest in the risky project $A$ if and only if:

$$
p\left(H+G_{H}\right)+(1-p)\left(L+G_{L}\right) \geq I+G_{I}
$$

This is equivalent to investing in the risky project $A$ for all values of $p$ such that:

$$
p \geq p_{G}^{o}=\frac{I+G_{I}-L-G_{L}}{H+G_{H}-L-G_{L}}
$$

\footnotetext{
${ }^{4}$ To obtain the paper's results it is not necessary for the full value of the growth opportunities to be lost, it is enough that the growth opportunities have a liquidation value which is smaller than the value obtained if the entrepreneur retains control of the firm. For simplicity, the growth opportunities' liquidation value is included in the terminal cash-flows $(H, L$ and $I)$ and $G$ includes only the illiquid component of the growth opportunities which is the entrepreneur's private information. Hereafter we will refer to $G$ as the firm's “illiquid growth opportunities" or, more simply, as the firm's "growth opportunities".

${ }^{5}$ We assume that $H+G_{H}>I+G_{I}>L+G_{L}$ : the values for the growth opportunities are not such as to reverse the ordering of the project's cash-flows.

${ }^{6}$ All the paper's results remain equally valid if the growth opportunities are the same across states of nature. That situation represents just a special case of the general model presented in the paper.
} 
$p_{G}^{O}$ represents the cut-off level that characterizes the investment policy of an all-equity firm. It constitutes the first-best investment policy, the one that maximizes total firm value. It defines the ideal benchmark, which would, in general, be obtained with complete contracting. We will be interested in analyzing the deviations from this benchmark due to incomplete contracting and to the presence of risky debt.

If the firm has risky debt outstanding with repayment value $F(I>F>L)$, the entrepreneur will invest in the risky project if the expected cash-flows she receives from the risky project are higher than those she receives from the riskless project. She will invest in the risky project A only if:7

$$
p\left\{[H-F]^{+}+1_{[H \geq F]} G_{H}\right\}+(1-p)\left\{[L-F]^{+}+1_{[L \geq F]} G_{L}\right\} \geq[I-F]^{+}+1_{[I \geq F]} G_{I}
$$

For I > F > L this is equivalent to: $p\left(H+G_{H}-F\right) \geq I+G_{I}-F$. The entrepreneur will then invest in the risky project $A$ for all values of $p$ such that:

$$
p \geq p_{G}^{F}=\frac{I+G_{I}-F}{H+G_{H}-F}
$$

To define the optimal investment policy of the firm with risky debt outstanding, what is crucial is the relation between $G_{L}$, the value of growth opportunities lost in bankruptcy, and $\mathrm{F}-\mathrm{L}$, the value in bankruptcy of limited liability. If $\mathrm{F}-\mathrm{L}>\mathrm{G}_{\mathrm{L}}$, then $p_{G}^{F}<p_{G}^{O}$ and there is riskshifting: the firm will invest too often in the risky project. If $\mathrm{F}-\mathrm{L}<\mathrm{G}_{\mathrm{L}}$ then $p_{G}^{F}>p_{G}^{O}$ and there is risk-avoidance: the firm will invest too often in the riskless project. If $F-L=G_{L}$, then $p_{G}^{F}=p_{G}^{O}$ and there are no agency costs of risky debt, the entrepreneur will follow the investment policy of the all-equity firm.

To understand the sources for deviations from the firm's first-best investment policy it is useful to rewrite $p_{G}^{F}$ as: 


$$
p_{G}^{F}=\frac{I+G_{I}-F}{H+G_{H}-F}=\frac{I+G_{I}-L-G_{L}-(\boldsymbol{F}-\boldsymbol{L})+\boldsymbol{G}_{\boldsymbol{L}}}{H+G_{H}-L-G_{L}-(\boldsymbol{F}-\boldsymbol{L})+\boldsymbol{G}_{\boldsymbol{L}}}
$$

Equation (8) highlights the impact of risky debt on the firm's investment policy. Risk-shifting incentives are created by subtracting the term F-L, which is positive, from the numerator and the denominator of $p_{G}^{o}$, the cut-off level that defines the optimal investment policy of an allequity firm. Risk-shifting incentives are induced then by the limited liability feature of corporate law. Risk-avoidance incentives are created by adding the value $G_{\llcorner}$to the numerator and the denominator of $p_{G}^{o}$. Risk-avoidance incentives are induced then by the loss of the illiquid growth opportunities, which occurs whenever the firm is liquidated at time 2 . The firm's optimal investment policy results from a trade-off between risk-shifting and risk-avoidance incentives. The presence of illiquid growth opportunities always mitigates the risk-shifting incentives created by limited liability. If $G_{L}>F-L$ the firm will present risk-avoidance instead of risk-shifting incentives.

Let us define $p^{*}(F)$ as the cut-off level (function of the outstanding debt level, F) above which the entrepreneur will invest in the risky project. Proposition 1 characterizes the entrepreneur's optimal investment policy, its deviations from the first-best investment policy, $p_{G}^{O}$, and the resulting agency problem.

Proposition 1: a) With debt of face value $F$ outstanding the entrepreneur implements the following investment policy:

$$
\begin{aligned}
& p^{*}(F)=p_{G}^{o}=\frac{I+G_{I}-L-G_{L}}{H+G_{H}-L-G_{L}} \quad \text { iff } \quad \mathrm{F} \leq \mathrm{L} \text { (debt is riskless); } \\
& =p_{G}^{F}=\frac{I+G_{I}-F}{H+G_{H}-F} \quad \text { iff } \quad \mathrm{L}<\mathrm{F} \leq \mathrm{I} \text {; } \\
& =0 \quad \text { iff } \quad F>I
\end{aligned}
$$

\footnotetext{
${ }^{7}$ By convention: $1_{[X \geq Y]}=1$ iff $X \geq Y ; 1_{[X \geq Y]}=0$ otherwise.
} 
b) With risky debt outstanding $(F>L)$ the entrepreneur will implement:

(1) - the first-best optimal investment policy iff $\mathrm{F}-\mathrm{L}=\mathrm{G}_{\mathrm{L}}\left(p^{*}(F)=p_{G}^{O}\right)$;

(2) - an investment policy that is riskier than the first-best optimal policy iff $F-L>G_{L}$ or $F>I$; in this case the entrepreneur presents risk-shifting behavior $\left(p^{*}(F)<p_{G}^{O}\right)$;

(3) - an investment policy that is less risky than the first-best optimal policy iff $F-L<G_{L}$; in this case the entrepreneur presents risk-avoidance behavior $\left(p^{*}(F)>p_{G}^{O}\right)$.

The main result of our model is the following: for a relevant subset of firms risky debt induces risk-avoidance incentives. This constitutes a reversal of traditional risk-shifting results. Our model confirms that, as stated in risk-shifting models, some firms, those with low economic prospects (with illiquid future opportunities with low economic value) will indeed overinvest in risky projects. The new contribution of our model is that it also shows that other firms, those with good illiquid opportunities, will not overinvest but will actually underinvest in risky projects. These entrepreneurs will optimally pass up good but risky investment projects because they do not want to risk losing control of the firm without realizing the value of the illiquid growth opportunities. Traditional risk-shifting models, which can be seen as a special case of the model presented here, assume that at the model's terminal date there are zero future opportunities (or that all growth opportunities are liquid and incorporated in the terminal cash-flows). We showed instead that if the firm has illiquid future opportunities the risk-shifting problem is always mitigated and that, for a relevant subset of firms, it will be reversed.

In synthesis, our model presents a new agency cost of risky debt and it shows that the impact of risky debt on the firm's risk choices depends on the value of the firm's future investment opportunities. The crucial feature of our model is that it extends the maturity of the equity contract beyond that of the debt contract: the firm is a going concern even at the model's terminal date. The presence of illiquid growth opportunities impacts the agency costs of risky debt: the firm will present risk-avoidance or risk-shifting incentives depending on the value of those growth opportunities. 
It is interesting to note that the correlation between the current investment policy and the level of future growth opportunities impacts the dimension of risk-avoidance incentives. It is easy to see, by simple substitution on (5) and (7), that firms which need to pursue risky investment policies to develop their growth opportunities $\left(G_{H}\right.$ and $G_{L}$ are high while $G_{I}$ is low; as an extreme case consider $\mathrm{G}_{H}=\mathrm{G}_{\mathrm{L}}$ and $\mathrm{G}_{\mathrm{I}}=0$ ) face particularly severe risk-avoidance incentives. This situation seems to represent a significant proportion of young firms in technology driven sectors with high economic potential (high growth opportunities) which needs to be pursued through risky investment policies. These risky investments are associated with uncertainty concerning the timing and the level of initial cash-flows. If financed by debt these firms would face an unappealing trade-off between a more conservative investment policy, which could compromise the value of their growth opportunities, and a riskier investment policy which could lead to bankruptcy. This type of firm avoids debt financing not because debt creates risk-shifting incentives, or Myers's underinvestment problems (see section V), but because debt creates risk-avoidance problems and the potential loss of their valuable growth opportunities.

\subsection{Using Option A nalogies}

Option Theory helps to explain why the presence of risky debt induces risk-shifting incentives. Two widely known option analogies illustrated the source for risk-shifting incentives. On the first analogy, sharehol ders have sold the firm to debthol ders and can get it back by paying the debt at maturity: they hold a call option on the firm's assets with an exercise price equal to the promised value of debt (Black and Scholes, 1973). Risk-shifting incentives arise, in this context, as an attempt to maximize the value of the call option, which benefits from an increase in the volatility of the firm's assets. The second analogy states that shareholders own the firm's assets and they also hold a limited liability put option on the firm's assets with exercise price equal to the face value of debt. In this context, risk-shifting incentives arise as the shareholders try to maximize the value of the limited liability put option. 
In both analogies shareholders increase the value of their option by increasing the volatility of the firm's assets, which results on risk-shifting incentives. These option analogies are very powerful but they are, nevertheless, simplifying analogies as it is clearly stated in the early papers in the area. Black and Scholes (1973) develop the call analogy stating carefully the underlying assumptions, two of which are particularly relevant for our purposes. One of their assumptions is to consi der that the firm debt is constituted by zero coupon bonds. Black and Scholes then add that if the company has coupon bonds instead of zero coupon bonds, the right comparison for the company's common stock is with a compound option: a call on a call, ..., on a call on the firm's assets. This compound option perspective is further explored by Geske (1977).

A nother assumption states that, when the debt is due, the firm will be either liquidated or totally recapitalized by paying off the old stockholders. This means that option analogies implicitly assume that the value of the firm as a going concern is the same as the firm's liquidation value. Black and Cox discuss this issue at the end of their paper:

"The introduction of bankruptcy costs might have a more important effect. ... However, their impact on our analysis should not be exaggerated. We are considering bankruptcy as simply the transfer of the entire ownership of the firm to the bondholders. The physical activities of the firm need not be affected" (Black and Cox, 1976, pg. 367).

The early concerns with the detail of the exact option analogies became, with time, more diluted and today we tend to associate the limited liability option with a straight put option. In particular, as we will just see, traditional finite-period models in Corporate Finance implement too closely a straight put option analogy. Figure 3 helps to explain the impact of option anal ogies in Corporate Finance models.

Figure 3.C, an infinite multiperiod model, clearly describes the firm as a going concern. One can picture an insider holding a portfolio of options which include several call options, representing the firm's future growth opportunities, and several limited liability put options, with multiple exercise dates. Exercising the limited liability option extinguishes the possibility to develop the remaining growth opportunities and, most likely, decreases the 
value of the growth options, which may become nearly worthless. ${ }^{8}$ This means that the exercise of a limited liability put option has a potentially large impact on the current value of the firm's assets, which is the option's underlying.

In corporate option analogies, unlike in financial options, there are strong interdependencies between the value of the "primitive" asset and the value of the "derivative" asset. In particular, the exercise of the "derivative" asset, the limited liability option, is likely to impact significantly the value of the "primitive" asset, the firm's assets. In a sense it is no longer clear which is the "primitive" asset and which is the "derivative" asset. As a result, the limited liability option is not a straight put option, it is instead a complex put option, which has a lower value than the corresponding straight put option.

Figure 3.A shows that in traditional finite-period models the limited liability option is exactly like a straight put option. As in these models the firm al ways ends in period 2, there is no difference between the value of the firm as a going concern and the firm's liquidation value. Here the exercise of the limited liability put option does not impact the value of the firm's assets. As a consequence, these models tend to overvalue the limited liability option, which means, in the context of our paper, that they tend to overemphasize the presence of riskshifting incentives.

The innovation of our model consists in the introduction, at the model's terminal date, of an additional option, which represents the firm's growth opportunities. This option, whose value is private information, creates the differentiation between the firm's value as a going concern and the firm's liquidation value. It extends the maturity of the equity contract beyond the maturity of the debt contract. Equation (8), in section II, shows that risk-shifting incentives arise by subtracting the term $\mathrm{F}-\mathrm{L}$ from the numerator and the denominator of $p_{G}^{O}$, the cut-off level which defines the optimal investment policy of an all-equity firm. This is exactly the value at exercise of a straight put limited liability option. Risk-shifting incentives are induced by a straight put option. Risk-avoidance incentives, on the other hand, are created by adding $\mathrm{G}_{\llcorner}$to the numerator and the denominator of $p_{G}^{O}$. This is exactly the value

\footnotetext{
${ }^{8}$ The exact impact on the value of the growth options will depend on how liquid or tradable these options are. It
} 
at exercise of the growth option, which will be lost if the firm is liquidated at time 2. In our model, the impact of risky debt on the firm's optimal risk choices is not only defined by the limited liability option, but it is the result of a trade-off between the value of the growth option and the value of the limited liability option.

Figure 3.B, which corresponds to our model, is a simplifying version of the multiperiod model, but it is one that nevertheless presents a balanced perspective on the portfolio of options held by the firm. By accounting for a illiquid growth option at the model's terminal date, it extends the maturity of the equity contract and incorporates a multiperiod dimension while retaining the flexibility of traditional finite-period models. In addition Figure 3 also highlights the potential limitations of assimilating complex corporate options to simple straight options.

\subsection{Risk-A voidance and the A gency Costs of D ebt}

\subsubsection{Optimal Investment Policy and the Agency Costs of D ebt}

The presence of illiquid growth opportunities has substantial impact on both the firm's optimal investment policy and the agency costs of risky debt. Figure 4 compares the optimal investment policies of firms with and without growth opportunities.

The firm's investment policy is defined by the cut-off level, $p^{*}$, which characterizes the entrepreneur's risk choices. While for a firm with no growth opportunities the optimal investment policy is increasing in risk for increasing $F$, for a firm with illiquid growth opportunities there is a non-monotonic relation between the debt level and the riskiness of the firm's investment policy. For given cash-flows and illiquid growth opportunities, the firm might exhibit, depending on the debt level F, an investment policy which is less risky, as risky or more risky than $p_{G}^{o}$, the first-best investment policy. The discontinuities in Figure

will depend on how liquid the firm's growth opportunities are. 
4.B are induced by the loss of the growth opportunities, which occurs when the entrepreneur is not able to retain control of the firm ( $G_{L}$ is lost when cash-flow $L$ is realized and $F$ is greater than $L, G$ is lost when I occurs and $F$ is greater than I).

The agency costs of risky debt measure the implications, in terms of total firm value, of deviations from the first-best investment policy. Given a cut-off level $p^{*}$, the entrepreneur will invest in the risky project only if she sees, at time 1, a p value equal or greater than $p^{*}$. As it is common knowledge, at date 0 , that $p$ is uniformly distributed over the interval $[0,1]$ then the net present value, at time 0 , of the investment policy with a cut-off level $p^{*}$ is equal to: 9

$$
N P V\left(p^{*}\right)=-I+\int_{0}^{p^{*}}\left(I+G_{I}\right) d p+\int_{p^{*}}^{1}\left[p\left(H+G_{H}\right)+(1-p)\left(L+G_{L}\right)\right] d p
$$

which is equivalent to:

$$
N P V\left(p^{*}\right)=-I+\left(I+G_{I}\right) p^{*}+\frac{\left(H+G_{H}\right)}{2}\left(1-p^{* 2}\right)+\frac{\left(L+G_{L}\right)}{2}\left(1-p^{*}\right)^{2}
$$

We derive the loss of value induced by the presence of risky debt by substituting in equation (11) for the optimal cut-off levels for an all-equity firm and for a firm with risky debt outstanding. The agency costs of debt, $A C(F)$, for a firm with no illiquid growth opportunities are equal to:

$$
A C(F)=N P V\left(p^{0}\right)-N P V\left(p^{F}\right)=\frac{1}{2}(H-L)\left(p^{0}-p^{F}\right)^{2}
$$

For a firm with illiquid growth opportunities, the agency costs of debt are equal to:

\footnotetext{
${ }^{9}$ As $p$ is uniformly distributed over the interval $[0,1]$ the probability, at time 0 , that $p$ will be greater than $p^{*}$ is equal to $1-p^{*}$. Then there is, at time 0 , a probability $p^{*}$ that the entrepreneur will invest in the riskless project and a probability $1-p^{*}$ that the entrepreneur will invest in the risky project.
} 


$$
A C(F)=N P V\left(p_{G}^{0}\right)-N P V\left(p_{G}^{F}\right)=\frac{1}{2}\left(H+G_{H}-L-G_{L}\right)\left(p_{G}^{0}-p_{G}^{F}\right)^{2}
$$

Figure 5 presents, for both types of firms, the agency costs of debt as a function of the firm's debt level, F. While for a firm with no growth opportunities the agency costs of debt are increasing in $\mathrm{F}$, for a firm with illiquid growth opportunities there is a non-monotonic relation between the debt level and the agency costs of debt. If the firm faces risk-avoidance incentives, an increase in the debt level reduces the risk-avoidance problem and the agency costs of debt. For these firms an increase in the debt level, F, increases the value of limited liability, F-L, which was smaller than the value of growth opportunities, $G_{L}$. As the two values become more similar there is a reduction in risk-avoidance incentives and on the overall level of agency costs.

If the firm al ready faces risk-shifting incentives, increases in the debt level create additional risk-shifting incentives and, consequently, increase the agency costs of debt. For these firms the value of limited liability, F-L, was al ready higher than the value of growth opportunities, $G_{L}$. Increasing the debt level, $F$, increases the incentives for risk-shifting and the agency costs of debt. These comparative statics results are formally expressed in the following propositions.

Proposition 2: For a firm with no growth opportunities, for given expected cash-flows:

a) The entrepreneur's investment policy is increasing in risk for increasing $F$. In the range of $F$, $L \leq F \leq I$, the investment policy is strictly increasing in risk for increasing $F$.

b) The agency costs of debt are increasing in the debt level $F$. In the range of $F, L \leq F \leq I$, the agency costs of debt are strictly increasing in $\mathrm{F}$.

Proposition 3: For a firm with illiquid growth opportunities $\left(G_{L}>0\right)$, for given expected cash-flows and growth opportunities:

a) There is a non-monotonic relation between the debt level, F, and the riskiness of the firm's investment policy. At $F=L$ there is a discontinuity associated with a (substantial) decrease in the level of risk of the investment policy. For $F>L$ the investment is increasing in risk for increasing $F$. b) There is a non-monotonic relation between the debt level, $F$, and the agency costs of debt: 
for $L<F<L+G_{L}$ the agency costs of debt are strictly decreasing in $F$;

for $L+G_{L}<F \leq I$ the agency costs of debt are strictly increasing in $F$.

Concerning the minimization of the agency costs of debt, our model presents two optima: riskless debt and an optimal level of risky debt. The optimality of riskless debt is a standard result, which is common with most previous models (see, e.g., Green, 1984). There is, though, another optimum debt level, $F=L+G_{L}$, where debt is risky and there are no agency costs of debt due to a perfect balance between risk-avoidance and risk-shifting incentives. The first-best investment policy is achieved even in the presence of risky debt. Our model shows that risky debt might create the right investment incentives concerning the firm's risk choices.

This paper is focused on the implications of a well-defined and common contract, risky debt, on the firm's investment policy. Our main interest is to characterize the incentives faced by the entrepreneur to deviate from a first-best investment policy and to present the resulting agency costs of debt. The paper is developed within an agency framework and it is not its purpose to demonstrate the optimality of the debt contract, which is done elsewhere (see, e.g., Townsend, 1979; Diamond, 1984; Gale and Hellwig, 1985; Hart and Moore, 1989). N everthel ess, one might ask whether, given the costs presented here, the firm should issue debt at time 0. As long as the benefits from debt, such as tax advantages (see, e.g., Kim, 1989) or signaling value (see, e.g., Ross, 1977; John, 1987), outweigh its agency costs, the entrepreneur will optimally choose, at time 0 , to issue debt and support its agency costs.

\subsubsection{Risk-A voidance and Bankruptcy Costs}

A pparently the loss of growth opportunities on the low states of nature might seem similar to just one more bankruptcy cost. Nevertheless risk-avoidance incentives are actually completely different from those created by pecuniary bankruptcy costs, as can be easily seen in the previous model. Pecuniary bankruptcy costs, P, represent a cash-flow loss suffered by debtholders in bankruptcy: instead of receiving the firm total cash-flow, $L$, they will realize 
only part of that cash-flow, L-P. Pecuniary bankruptcy costs do not impact any cash-flows received by the entrepreneur at time 2 . In consequence, they do not impact the entrepreneur's investment decision: pecuniary bankruptcy costs do not change the entrepreneur's risk-shifting or risk-avoidance incentives. 10

In a rational expectations perspective debtholders will correctly anticipate the pecuniary bankruptcy costs and price them at time 0 . So pecuniary bankruptcy costs impact ex-ante, at time 0 , the entrepreneur's behavior, such as the design and structure of financial claims, but they do not impact ex-post, at time 1, the entrepreneur's investment decisions, such as her risk choices. The incentives created by pecuniary bankruptcy costs are then completely different from those created by illiquid growth opportunities. While the potential loss of growth opportunities impacts, ex-post, the entrepreneur's risk choices creating riskavoidance incentives, pecuniary bankruptcy costs impact only, ex-ante, the pricing of corporate debt.

Risk-avoidance incentives are motivated in this paper by illiquid growth opportunities but they could be motivated instead by non-pecuniary bankruptcy costs (Diamond, 1984) or by private benefits of control (Harris and Raviv, 1988, 1991; Diamond, 1991). All these features have something in common: they represent costs that the entrepreneur suffers in bankruptcy which are not covered by limited liability. They are all different, cumulative sources for an entrepreneur to exhibit risk-avoidance incentives. Our paper nevertheless differs from the above papers because it is focused on the distortions introduced by these features on the entrepreneur's investment policy. In particular, it is centered on the entrepreneur's risk choices and the resulting agency costs.

Our paper also differs because, although they impact similarly the firm's risk choices, the nature of the growth opportunities is quite distinct from both private benefits of control and non-pecuniary bankruptcy costs. The value of the growth opportunities is completely

\footnotetext{
${ }^{10}$ The cut-off levels which define the entrepreneur's optimal policy are not affected by $P$, the pecuniary bankruptcy costs. $p^{O}$ and $p_{G}^{O}$ are not changed because an all-equity firm does not face bankruptcy costs; $p^{F}$ and $p_{G}^{F}$ are not changed because the cash-flows received by debtholders in bankruptcy ( $L$ or $L-P$ ) do not enter into the definition of the entrepreneur's optimal cut-off levels.
} 
defined by regular cash-flows which will be available to the firm in the future. Our paper is focused on the temporal structure of the firm's cash-flows while both non-pecuniary bankruptcy costs and private benefits of control request the use of non-cash-flow features.

In synthesis, the presence of illiquid growth opportunities, private benefits of control and non-pecuniary bankruptcy costs suggests that instances of risk-avoidance incentives must be quite pervasive in reality.

\subsubsection{Risk-A voidance and Renegotiation}

It is interesting to note that remedies that mitigate risk-shifting problems, such as convertible debt (Green, 1984) and the design of managerial contracts (John and John, 1993), do not have impact on risk-avoidance problems. In a risk-avoidance situation the entrepreneur does not invest in risky projects because they may originate default in the low states of nature, and consequently, the loss of the firm's growth opportunities. Remedies for risk-avoidance problems should diminish the likelihood of default or assure that the entrepreneur retains control of the firm even after default occurs. Debt renegotiation is then a potential tool to address risk-avoidance incentives. This section shows that if debt renegotiation is feasible at time 2, it mitigates risk-avoidance incentives and increases risk-shifting incentives. Nevertheless, as long as renegotiation is costly or as long as the entrepreneur is uncertain, at time 1 , of the terms or feasibility of debt renegotiation, then she will still present riskavoidance incentives.

The nature of the firm's growth opportunities can be seen under three different general perspectives. The first perspective, which we have followed so far, assumes that at least part of the firm's growth opportunities is illiquid, because their value is privately observed by the entrepreneur. Implicitly this perspective assumes that debt renegotiation is not feasible at time 2. All firms that default on their debt, claim that they have high growth opportunities and the creditors are not able to distinguish those with high growth opportunities from those with low growth opportunities. These limitations to renegotiation are similar to those 
considered by the literature on inefficient liquidation or liquidity risk (see, e.g., Diamond, 1991; Hart and Moore, 1989; Bolton and Scharfstein, 1990). This perspective shows that the presence of illiquid growth opportunities is likely to generate inefficient liquidation. This perspective seems reasonable in terms of empirical counterparts and it was useful to highlight, as simply as possible, the paper's main results. It is not, though, a necessary assumption for the entrepreneur to present risk-avoidance behavior, as we shall see.

A second perspective assumes that the firm's growth opportunities areall public information and contractible. In this case they are liquid and they can be assimilated to the firm's current cash-flows: the classic risk-shifting model is valid and there are no risk-avoidance incentives. A third perspective assumes that the value of the growth opportunities is public information but not verifiable so contracts cannot be written contingent on this value. The growth opportunities remain illiquid but there are strong incentives, in default, for debt renegotiation, as both creditors and debtors see that the firm value increases if it is allowed to continue. This is the perspective adopted in the following model which expands our basic model to include debt renegotiation.

We now assume that, at time 1 the entrepreneur knows that, at time 2, the value of the firm's growth opportunities will be, with probability $\alpha$, non-verifiable public information. With probability $1-\alpha$, the value of the growth opportunities remains private information and there is no renegotiation. We also assume, without loss of generality, that debt renegotiation is costly: every time it occurs it creates a cost $R$ to be subtracted from the firm's remaining cashflows. If renegotiation occurs the entrepreneur and her creditors will bargain over the specifics of the new debt contract. We assume the following outcome for the bargaining process: if the value of the firm's growth is enough to pay in full the debt amount (if $F+R \leq L+G_{L}$ ), then renegotiation consists simply in rescheduling debt payments. Otherwise, if a delayed full payment is not feasible (if $F+R>L+G_{L}$ ), debtors either liquidate the firm (if $R \geq G_{L}$ ), or they offer the entrepreneur (if $R<G_{L}$ ) an amount $\varepsilon$ from the firm's 
future cash-flows to induce her to keep running the firm and realize its growth opportunities.11

In this setting the entrepreneur will invest in the risky project A only if:

$$
\begin{gathered}
p\left\{[H-F]^{+}+1_{[H \geq F]} G_{H}+1_{[H<F]} 1_{\left[R<G_{H}\right]} \alpha \operatorname{Max}\left[H+G_{H}-R-F, \varepsilon\right]\right\}+ \\
+(1-p)\left\{[L-F]^{+}+1_{[L \geq F]} G_{L}+1_{[L<F]} 1_{\left[R<G_{L}\right]} \alpha \operatorname{Max}\left[L+G_{L}-R-F, \varepsilon\right]\right\} \geq \\
\geq[I-F]^{+}+1_{[I \geq F]} G_{I}+1_{[I<F]} 1_{\left[R<G_{I}\right]} \alpha \operatorname{Max}\left[I+G_{I}-R-F, \varepsilon\right]
\end{gathered}
$$

For I > F > L this is equivalent to:

$$
p\left(H+G_{H}-F\right)+(1-p) 1_{\left[R<G_{L}\right]} \alpha \operatorname{Max}\left[L+G_{L}-R-F, \varepsilon\right] \geq I+G_{I}-F
$$

In the A ppendix we characterize the entrepreneur's optimal policy in this setting. The results show that renegotiation increases the entrepreneur's expected value associated with therisky investment. The risky project becomes relatively more attractive and consequently the expectation of renegotiation increases theentrepreneur's incentives to risk-shift. For the same reason renegotiation tends, in general, to mitigate the entrepreneur's risk-avoidance incentives. The higher the renegotiation costs and the entrepreneur's uncertainty concerning the terms or feasibility of debt renegotiation, the smaller will be the impact of renegotiation on the entrepreneur's risk-avoidance incentives. For firms with very valuable $G_{L}$, even a small probability of failure in renegotiation can createlarge risk-avoidance incentives.

\footnotetext{
${ }^{11}$ This section main result - ex-ante expectations of renegotiation mitigate risk-avoidance incentives and increase risk-shifting incentives - is robust to other renegotiation outcomes, as long as the entrepreneur expects, at time 1, to receive some cash-flows after default.
} 


\subsection{Risk-Shifting, Risk-A voidance and M yers' U nderinvestment}

\subsubsection{M yers's Underinvestment and G rowth Opportunities}

The presence of illiquid growth opportunities not only impacts risk-shifting incentives but it affects as well the incentives for a Myers' (1977) underinvestment problem. In this section, we will show that Myers's underinvestment incentives are reduced if the firm has valuable illiquid growth opportunities. In addition, we will show that if the value of those growth opportunities is sufficiently high, Myers's underinvestment incentives are completely eliminated. Figure 6 redraws Myers' problem (1977, Figure 2, pg. 153) incorporating the firm's illiquid growth opportunities, G.

In this model the entrepreneur has, at time 1 , a single investment project available. At time 2 the project generates cash-flows that depend on the state of nature s. The entrepreneur sees privately, at time 1, the state of nature and decides whether to invest in the project. From the entrepreneur's perspective all uncertainty concerning the future cash-flows is already removed at the time of investing. This implies that Myers' problem is concerned with the firm's propensity to invest and not with the firm's risk choices, which is the focus of the riskavoidance model. The agency problem arises because contracts contingent on s cannot be enforced: s is privately observed and is not verifiable.

Figure 6 incorporates illiquid growth opportunities in Myers' model. The presence of illiquid growth opportunities extends the maturity of the equity contract beyond the model's terminal date and beyond debt's maturity. In linewith the risk-avoidance model, we assume that the entrepreneur has private information concerning the value of the firm's growth opportunities. To reflect more clearly the impact of risky debt on the firm's investment policy we assume, initially, that the value of the growth opportunities, $G$, is the same across all states of nature. Later, we relax this assumption which is not crucial to obtain our main results. We also assume that the value of $G$ is independent from the entrepreneur's decision concerning the current investment project. 
In an all-equity firm the entrepreneur's optimal investment policy is to invest in the current project if it has a positive net present value. She will invest in the current project in any state of nature at least as favorable as $\mathrm{s}_{\mathrm{a}}$. This decision considers only the project's cash-flows and ignores the firm's growth opportunities. In an all-equity firm the entrepreneur ignores the value of the growth opportunities to make her current investment decision, because she will be al ways able to explore later the growth opportunities. She will retain control of the firm, independently of her current investment decision.

The optimal investment policy of a firm with no growth opportunities and with debt of promised payment $F$ outstanding is to invest in the current project in those states of nature at least as favorable as $\mathrm{s}_{\mathrm{b}}$. The firm presents a Myers's underinvestment problem because it does not invest in the current project in those states of nature in the interval $\left[\mathrm{s}_{\mathrm{a}}, \mathrm{s}_{\mathrm{b}}\right)$, states for which the project presents a positive net present value. The entrepreneur does not invest in the current project because the cash-flows from the project will first be used to pay $F$ and, consequently, in those states, the remaining value accruing to the entrepreneur will be less than the initial investment I. The project's net present value is positive, but its net present value to the entrepreneur is negative. The firm suffers from a debt overhang problem. The triangle $A B B^{\prime}$ represents the agency costs of debt, resulting from an investment policy which differs from the one that maximizes the total firm value.

The optimal investment policy of a firm with illiquid future opportunities, G, and with debt of promised payment $F$ outstanding is to invest in the current project in those states of nature at least as favorable as $s_{c}$. To make the current investment decision, the entrepreneur now considers both the cash-flows generated by the current project and the value of the firm's future growth opportunities. As a result the debt overhang problem is mitigated. The entrepreneur invests in the current project even in those states of nature in the interval $\left[\mathrm{s}_{c}, \mathrm{~S}_{b}\right)$, for which the cash-flows the entrepreneur receives from the project are not enough to cover her investment I. Nevertheless the current project is worthwhile for her in those states, because it enables the entrepreneur to pay off the debt and to retain control of the firm. The current project is implemented because it enables the entrepreneur to retain access to the 
firm's future growth opportunities. ${ }^{12}$ This firm still presents a Myers's underinvestment problem, as it does not invest in the current project in those states of nature in the interval $\left[s_{a}, s_{c}\right)$, states for which the project has a positive net present value. N evertheless Myers's underinvestment problem is mitigated and the agency costs of debt are reduced to the triangle $A C C^{\prime}$. If the value of the growth opportunities at $s_{a}$ is equal to or bigger than $F$, then $\mathrm{s}_{c}$ will coincide with $\mathrm{s}_{\mathrm{a}}$ and Myers's underinvestment problem disappears.

Figure 6 presents the same growth opportunities, G, across all states of nature. Figure 6.A presents two additional examples where the value of the growth opportunities differs across states of nature. The main result is the same: Myers' underinvestment problem is reduced in both cases, but the examples present a difference in the magnitude of the effect. The exact impact on Myers's underinvestment problem is a function of the correlation between the value of the illiquid growth opportunities and the level of the firm's cash-flows at time 2 . For strong positive correlations the reduction in Myers' underinvestment incentives is smaller than for negative correlations. The higher the level of growth opportunities around and to the right of $s_{a}$, the closer $s_{c}$ will be to $s_{a}$, and the lower Myers' underinvestment problem.

\subsubsection{Risk-Shifting, Risk-A voidance and Myers's Underinvestment}

In this section we develop a model which combines risk-shifting and risk-avoidance incentives with Myers' underinvestment problem. The purpose is to clarify further the nature of the different agency costs of debt. The model is similar to the risk-avoidance model of section II, but now the entrepreneur has three alternatives at time 1 . She can invest in the risky project or in the riskless project and she can also pay herself an amount $D$ as a (potentially high) dividend.13 This extended model is depicted in Figure 7. It is useful to note

\footnotetext{
${ }^{12}$ An alternative way for the entrepreneur to retain access to the firm's growth opportunities is to pay $F$ directly from the entrepreneur's wealth, without investing $I$, but this is a worse alternative as the current project has a positive net present value.

${ }^{13}$ To incorporate Myers' underinvestment problem the model allows for a dividend payment at time 1 : D $\leq \mathrm{I}$. The distribution of a dividend $D$ is a simple way to create, at time 1 , a Myers' underinvestment problem, but it is not the only potential source of an underinvestment problem. For an underinvestment problem to occur what is crucial is to have a mechanism which allows that the cash raised at time 0 by the firm is no longer available for
} 
that there is no reason for $G_{D}$, the firm's growth opportunities associated with no investment at time 1 , to be bigger than $G_{1}$, the growth opportunities associated with the riskless investment. We will then assume, without loss of generality, that $G_{1} \geq G_{D}$. This inequality implies that for an all-equity firm the payment of a dividend $D$ is weakly dominated by the riskless project, because the net present values of the remaining cash-flows associated with both alternatives are equival ent. This means that, as expected, for an all-equity firm there is no Myers' underinvestment problem.

In an all-equity firm the entrepreneur will invest in the project with the highest expected net present value. She will invest in the risky project $A$ if and only if $p\left(H+G_{H}\right)+(1-p)\left(L+G_{L}\right) \geq I+G_{I}$. This is equivalent to investing in the risky project A for all values of $p$ such that:

$$
p \geq p_{G}^{o}=\frac{I+G_{I}-L-G_{L}}{H+G_{H}-L-G_{L}}
$$

The entrepreneur will invest in the riskless project B only if $p<p_{G}^{O}$.

If the firm has risky debt outstanding with repayment value $F(I>F>L)$, the entrepreneur will invest in the risky project $A$ only if the risky project is more valuable for her than the riskless project B, $p\left(H+G_{H}-F\right) \geq I+G_{I}-F$, and more valuable than paying the dividend D , $p\left(H+G_{H}-F\right) \geq D$. This is equivalent to investing in the risky project A for all values of p such that: 14

$$
p \geq p_{G}^{F}=\frac{I+G_{I}-F}{H+G_{H}-F} \quad \text { and } \quad p\left(H+G_{H}-F\right) \geq D
$$

\footnotetext{
investment at time 1. The cash raised can be either distributed as a dividend to shareholders, dissipated on managers perquisites, or previously invested in projects which turned out to offer bad outcomes. It is possible to develop a more complex setting which makes Myers' problem more interesting, but we believe that the main intuitions are maintained in this simple version.

${ }^{14}$ As expected the introduction of a Myers' underinvestment problem does not impact the optimal cut-off levels $p_{G}^{O}$ and $p_{G}^{F}$, which are exactly the same as in the risk-shifting model with growth opportunities.
} 
The entrepreneur will invest in the riskless project B only if the riskless project is more valuable for her than the risky project A, $p\left(H+G_{H}-F\right)<I+G_{I}-F$, and more valuable than paying the dividend $\mathrm{D}, I+G_{I}-F \geq D$. This is equivalent to investing in the riskless project $B$ for all values of $p$ such that:

$$
p \leq p_{G}^{F}=\frac{I+G_{I}-F}{H+G_{H}-F} \text { and } I+G_{I}-F \geq D
$$

The entrepreneur will not invest at time 1 and will pay instead a dividend $D$ only if the dividend is more valuable for her than the best of the investment projects:

$$
D \geq \max \left[p\left(H+G_{H}-F\right), I+G_{I}-F\right]
$$

The optimal investment policy of the firm with risky debt outstanding can be seen as an interaction between equation (19) and the results of our previous risk-shifting model with growth opportunities. If equation (19) is verified there is a Myers' underinvestment problem. Otherwise, if $F \leq L$ the debt is riskless and there are no agency costs of debt; if $F>L$ what is crucial is the relation between F-L and $\mathrm{G}_{\mathrm{L}}$. If F-L $>\mathrm{G}_{\mathrm{L}}$ then $p_{G}^{F}<p_{G}^{O}$ and there is a riskshifting problem; if $\mathrm{F}-\mathrm{L}=\mathrm{G}_{\mathrm{L}}$ then $p_{G}^{F}=p_{G}^{O}$ and there are no agency costs of risky debt; if $\mathrm{F}-\mathrm{L}<\mathrm{G}_{\mathrm{L}}$ then $p_{G}^{F}>p_{G}^{O}$ and there is a risk-avoidance problem.

In conclusion:

a) - there is a Myers' underinvestment problem when the expected cash-flows at time 2 and the associated growth opportunities have a lower value than the amount the entrepreneur is able to take away from the firm (or is required to put in the firm) at time 1;

b) - there is a risk-shifting problem if a) is not true and the growth opportunities in the bad states of nature are less valuable than the value of limited liability;

c) - there is a risk-avoidance problem if a) is not true and the growth opportunities in the bad states of nature are more valuable than the value of limited liability. 
Some papers have implicitly considered an opposition between risk-shifting incentives (overinvestment in risky projects) and Myers' underinvestment incentives (see, e.g., Parrino and Weisbach, 1997; Chen, Weston and Altman, 1995). The above model shows that riskshifting incentives are instead in contrast with risk-avoi dance incentives (underinvestment in risky projects) and that both effects are conceptually very different from Myers' underinvestment problem. In Myers framework there is a global underinvestment problem as the shareholders decision to invest increases the value of bondholders claims. This underinvestment problem can be contrasted with overinvestment problems such as those motivated by managerial preference for bigger firms (see, e.g., Jensen, 1986; Stulz, 1990). Myers' underinvestment and managerial overinvestment problems are both concerned with the firm's investment level or, in other words, its investment propensity.

In risk-avoidance and risk-shifting problems what is relevant is not the firm's investment level but only its risk characteristics: the firm's risk choices. In the risk-shifting, riskavoidance model of section II there is no global underinvestment or overinvestment problem - the firm will invest the same amount regardless of the choice of project. Myers' underinvestment problems and managerial overinvestment problems are concerned with the firm's investment level: with the amount to be invested by the firm. Risk-avoidance and riskshifting problems are concerned with the firm's risk choices: with the type of projects in which the firm will invest its resources. All the above effects have something in common: they are all concerned with deviations from the firm's first-best investment policy. Neverthel ess the above effects are distinguishable along those two dimensions: the firm's investment propensity and its risk choices.

Table 1 summarizes the above discussion. With the exception of managerial overinvestment, all the remaining deviations from the firm's first-best investment policy are created by the presence of risky debt. 


\begin{tabular}{|c|c|c|}
\hline \multicolumn{3}{|c|}{ Deviations from the firm's first-best investment policy concerning: } \\
\hline The firm's investment level: & $\begin{array}{c}\text { Managerial overinvestment } \\
\text { (Jensen, 1986; Stulz, 1990) }\end{array}$ & $\begin{array}{c}\text { Myers' underinvestment } \\
\text { (Myers, 1977) }\end{array}$ \\
\hline Thefirm's risk choices: & $\begin{array}{c}\text { Risk-shifting } \\
\text { (Jensen and Meckling, 1976; } \\
\text { Green, 1984) }\end{array}$ & Risk-avoidance \\
\hline
\end{tabular}

\section{Table 1}

It is interesting to note that each of the above deviations from the firm's first-best investment policy arises due to a different motivation. In particular, in a Myers' underinvestment problem, shareholders underinvest in riskless projects because they will lose control of the firm in any case. Instead of investing in the firm they prefer to take as much money out of the firm as they can, or at least to minimize the money they put in the firm before losing control of it. In a risk-avoidance problem shareholders avoid risky projects precisely for the opposite reason: they do not want to risk losing control of the firm.

The results presented in this section show that for a given debt level, the riskier and the more valuable the firm's growth opportunities are, the more likely they are to create a riskavoidance problem and not a Myers underinvestment problem. The less risky and the less valuable the firm's growth opportunities are, the more likely they are to create a Myers underinvestment problem and not a risk-avoidance problem. Our results suggest that it is likely that in the early stages of financial distress, and at least for firms with valuable growth opportunities, risk-avoidance incentives arethe dominant deviations from the firm's optimal investment policy. In later stages of financial distress, for firms with low or deteriorated economic prospects, risk-shifting and Myers' underinvestment incentives become dominant.

Our model suggests that the firm's reaction to financial distress is crucially dependent on its economic prospects. In a situation of financial distress a firm with low economic prospects 
presents risk-shifting and Myers' underinvestment problems while a firm with good economic prospects presents risk-avoidance problems. On the other hand, Jensen (1986) states that if the firm presents a good financial situation and low economic prospects, managers tend to overinvest: they will invest the firm's resources in negative present value projects. These ideas are summarized in Table 2.

\begin{tabular}{|c|c|c|c|}
\hline \multirow{2}{*}{\multicolumn{2}{|c|}{$\begin{array}{l}\text { The impact of economic prospects } \\
\text { and financial distress on the firm's } \\
\text { investment incentives: }\end{array}$}} & \multicolumn{2}{|c|}{ Economic Foundations } \\
\hline & & Good & Bad \\
\hline \multirow{2}{*}{$\begin{array}{l}\text { Financial } \\
\text { Situation }\end{array}$} & Good & $\begin{array}{c}\text { First-best } \\
\text { investment policy }\end{array}$ & $\begin{array}{c}\text { Managerial } \\
\text { overinvestment }\end{array}$ \\
\hline & Bad & Risk-avoidance & $\begin{array}{c}\text { Risk-shifting and Myers' } \\
\text { underinvestment }\end{array}$ \\
\hline
\end{tabular}

Table 2

\subsection{D iscussion and Empirical Implications}

In terms of methodology this paper makes two related contributions: the first is concerned with adding a multiperiod perspective to finite-period models and the second is concerned with the application of option anal ogies to Corporate Finance settings. To model the firm's behavior in Corporate Finance we ideally would like to work in a multiperiod, infinite horizon, setting. For tractability most Corporate Finance models have restricted the analysis to finite period models, but that restriction has generally ignored the value of the firm as a going concern. This paper presents a possible approximation to multiperiod settings: it considers that at the model's terminal date the firm still has some valuable future 
opportunities which are not immediately convertible in cash-flows. This is a step towards a multiperiod analysis in the sense that although the model retains the flexibility of traditional finite period settings it al so incorporates the firm future opportunities. The firm is modeled as a going concern and the future, although not explicitly modeled, is incorporated in the problem by considering the value of the firm's future growth opportunities. The presence of illiquid growth opportunities extends the maturity of the equity contract beyond the model's terminal date and the maturity of the debt contract. This approach is likely to add value to other finite period Corporate Finance models.

The use of option analogies in Corporate Finance has brought powerful insights and has helped to clarify difficult concepts and intuitions. Nevertheless, the present paper shows that some care must be taken in the application of option analogies to the Corporate Finance setting. In general, it seems that real options are rarely straight options, they involve several interdependencies, which are usually not present in financial options. In particular, this paper shows that finite period models tend to adopt the limited liability straight put option analogy too literally, by restricting the life of the firm to the period which ends with the option's exercise date. As a result the nature of the firm as a going concern and the inherent complexities are lost in these models.

Risk-avoidance incentives predict that firms with high illiquid future economic rents avoid debt and, if they require outside financing, they prefer to use outside equity or venture capital. These arefinancial contracts which minimize the risk of transfer of control in thelow states of nature and so minimize the loss of value associated with risk-avoidance behavior. We should note that the claims that solve the risk-avoidance problem also solve the riskshifting problem; but the reverse is not true.

Risk-avoidance behavior occurs if future economic rents are private information. This is consistent with the observation that "leverage does not reduce growth for firms known to have good investment opportunities but it is negatively related to growth for firms whose growth opportunities are either not recognized by the capital markets or are not sufficiently valuable to overcome the effects of their debt overhang" (Lang, Ofek and Stulz, 1996). Riskavoidance behavior does not occur if future economic rents can be transformed in liquid 
cash-flows, if they are marketable. In these instances it is likely that the firm will be able to renegotiate its (defaulted) debt contracts.

A possible extension of the results of this paper is the one concerned with the risk incentives created by a flat-rate deposit insurance system. Our results are similar to the intuitions developed by the banking literature adopting the charter value perspective: Keeley (1990) shows that risk-shifting becomes an issue in banks only when their charter value (their value as a going concern, the val ue of their future opportunities) decreases. Risk-shifting incentives of a flat deposit insurance premium become a problem only when deregulation increases competition in banking, resulting in lower charter values, at least for some banks or thrifts. This is equivalent to say that high charter values induce risk-avoidance incentives even with a flat-rate deposit insurance system. Only when the bank's charter value is reduced, or equival ently its future economic rents are reduced, do the risk-shifting incentives induced by high leverage and a flat-rate deposit insurance premi um become dominant.

\subsection{Conclusion}

The result that risky debt induces incentives for risk-shifting (overinvestment in risky projects) constitutes a major tenet of Corporate Finance theory. This paper shows that the above result is subject to certain qualifications: risky debt does not necessarily create overinvestment incentives, in many instances it will actually create the opposite incentives. With risky debt outstanding a firm with low economic prospects will indeed overinvest in risky projects, but firms with good illiquid opportunities will instead underinvest in risky projects. The owners of these firms will optimal ly pass up good but risky investment projects because they do not want to risk losing control of the firm: they present risk-avoidance behavior. The paper al so shows that the presence of illiquid growth opportunities mitigates and can even eliminate Myers' underinvestment problem. In synthesis, illiquid growth opportunities crucially impact previous results concerning the agency costs of risky debt. 
Risk-avoidance incentives hel p to explain why firms with risky debt outstanding and illiquid growth opportunities present conservative investment policies. The owners of these firms, including highly levered banks and LBO firms, avoid investments which are too risky because they do not want to lose control of the firm before realizing its growth opportunities. Our paper also contributes to understand why young technology driven firms avoid issuing debt. It explains why firms with high illiquid growth opportunities present, ceteris paribus, lower levels of debt than those of firms with low or liquid growth opportunities. Firms with illiquid growth opportunities avoid debt financing not because debt creates for them riskshifting incentives or Myers's underinvestment problems, but because debt creates riskavoidance problems and the potential loss of their valuable growth opportunities.

In terms of methodology this paper makes two contributions: we argued that considering future economic rents in finite-period models retains the flexibility of those models while adding a multiperiod perspective. New results are derived from extending the maturity of equity beyond debt's maturity in finite period settings. This paper also showed that finite period Corporate Finance models implicitly associate limited liability with a straight put option. In consequence, risky debt generates al ways risk-shifting incentives in these models, as, ex-post, the entrepreneur tries to maximize the value of the put option. We demonstrate that the firm's investment incentives are substantially more complex than the simple riskshifting results obtained in finite-period models. These models fail to account for the fact that the firm has other options outstanding, particularly growth options, and that exercising the put option provided by limited liability inhibits the exercise of the firm's remaining options. To define the risk incentives created by risky debt what is crucial is the relation between expost gains due to limited liability and the losses due to forgoing the firm's future growth opportunities. 


\section{Appendix}

Proof of Lemma 1: An investment policy with a cut-off level generates the following cash-flow distribution: $\mathrm{H}+\mathrm{G}_{\mathrm{H}}$ occurs with probability $\frac{1}{2}\left(1-p^{* 2}\right)=\int_{p^{*}}^{1} p d p, \mathrm{I}+\mathrm{G}_{\mathrm{I}}$ occurs with probability $p^{*}=\int_{0}^{p^{*}} d p$, and $\mathrm{L}+\mathrm{G}_{\mathrm{L}}$ occurs with probability $\frac{1}{2}\left(1-p^{*}\right)^{2}=\int_{p^{*}}^{1}(1-p) d p$. Using $\mathrm{p}_{1}<\mathrm{p}_{2}$ in the terminal cash-flow distribution proves Lemma 1. Q.E.D.

Proof of Proposition 1: a) The entrepreneur will invest in the risky project if and only if equation (6) is verified. For $F \leq L$, debt is riskless and equation (6) is equivalent to $p\left(H-F+G_{H}\right)+(1-p)\left(L-F+G_{L}\right) \geq I-F+G_{I}$, which is equivalent to (4) and (5). Then $p^{*}(F)=p_{G}^{O}$.

For $\mathrm{L}<\mathrm{F} \leq \mathrm{I}$, debt is risky and $[L-F]^{+}+1_{[L>F]} G_{L}=0$. Equation (6) is equivalent to $p\left(H+G_{H}-F\right) \geq I+G_{I}-F$ and to (7). Then $p^{*}(F)=p_{G}^{F}$.

For $\mathrm{F}>\mathrm{I},[I-F]^{+}+1_{[I>F]} G_{I}=[L-F]^{+}+1_{[L>F]} G_{L}=0$. (6) is equivalent to $p\left(H+G_{H}-F\right) \geq 0$ which is equivalent to $p \geq 0$. Then $p^{*}(F)=0$.

b) For $\mathrm{L}<\mathrm{F} \leq \mathrm{I}, p^{*}(F)=p_{G}^{F}$ and equation (8) shows that $p_{G}^{F}=p_{G}^{O}$ iff $\mathrm{F}-\mathrm{L}=\mathrm{G} \mathrm{L}, p_{G}^{F}<p_{G}^{O}$ iff $\mathrm{F}-\mathrm{L}>\mathrm{G}_{\mathrm{L}}, p_{G}^{F}>p_{G}^{O}$ iff $\mathrm{F}-\mathrm{L}<\mathrm{G}_{\mathrm{L}}$. For $\mathrm{F}>\mathrm{I}, p^{*}(F)=0<p_{G}^{O}$ from a). The result follows from Lemma 1. Q.E.D.

Proof of Proposition 2: a) For $\mathrm{F} \leq \mathrm{L}, p^{*}(F)=p^{o}$ by (1). For $\mathrm{L}<\mathrm{F}_{1}<\mathrm{F}_{2} \leq \mathrm{I}$, (3) implies that $p^{*}\left(F_{2}\right)<p^{*}\left(F_{1}\right)<p^{O}$. For $\mathrm{F}>\mathrm{I},(2)$ implies that $p^{*}(F)=0=p^{*}(I)$. The result follows from Lemma 1.

b) For $\mathrm{F} \leq \mathrm{L}, p^{*}(F)=p^{O}$ from a). This implies that $A C(F)=0$. 
For $\mathrm{L}<\mathrm{F} \leq \mathrm{I}, p^{*}(F)=p^{F}$ and $A C(F)=N P V\left(p^{0}\right)-N P V\left(p^{F}\right)=\frac{1}{2}(H-L)\left(p^{0}-p^{F}\right)^{2}$. Then $\frac{\partial A C(F)}{\partial F}=\left(p^{0}-p^{F}\right) \frac{(H-L)(H-I)}{(H-F)^{2}}$. From a) $p^{o}>p^{F}$, which implies $\frac{\partial A C(F)}{\partial F}>0$.

For $\mathrm{F}>\mathrm{I}, p^{*}(F)=0=p^{*}(I)$ from a). Then $A C(F)=A C(I)$. The agency costs of debt are then increasing in $F$ and strictly increasing in $F$ in the range $L \leq F \leq$ I. Q.E.D.

Proof of Proposition 3: a) For $\mathrm{F} \leq \mathrm{L}, p^{*}(F)=p_{G}^{o}$ by (9). For $\mathrm{L}<\mathrm{F}_{1}<\mathrm{F}_{2} \leq \mathrm{I}$, (8) implies that $p^{*}\left(F_{2}\right)<p^{*}\left(F_{1}\right)$. For $\mathrm{L}<\mathrm{F}<\mathrm{L}+\mathrm{G}_{\mathrm{L}}, p^{*}(F)>p_{G}^{O}$ by (8), creating non-monotonicity. For $\mathrm{F}>\mathrm{I}$, (9) implies that $p^{*}(F)=0<p^{*}(I)$. The result follows from Lemma 1.

b) For $\mathrm{F} \leq \mathrm{L}, p^{*}(F)=p_{G}^{O}$ from a). This implies that $A C(F)=0$. For $\mathrm{L}<\mathrm{F} \leq \mathrm{I}, p^{*}(F)=p_{G}^{F}$ and $A C(F)=N P V\left(p_{G}^{0}\right)-N P V\left(p_{G}^{F}\right)=\frac{1}{2}\left(H+G_{H}-L-G_{L}\right)\left(p_{G}^{0}-p_{G}^{F}\right)^{2}$. Then $\frac{\partial A C(F)}{\partial F}=\left(p_{G}^{O}-p_{G}^{F}\right) \frac{\left(H+G_{H}-L-G_{L}\right)\left(H+G_{H}-I-G_{I}\right)}{\left(H+G_{H}-F\right)^{2}}$. For $\mathrm{L}<\mathrm{F}<\mathrm{L}+\mathrm{G}_{\mathrm{L}}, p_{G}^{O}<p_{G}^{F}$, which implies $\frac{\partial A C(F)}{\partial F}<0$. For $\mathrm{L}+\mathrm{G}_{\mathrm{L}}<\mathrm{F} \leq \mathrm{I}, p_{G}^{o}>p_{G}^{F}$, which implies $\frac{\partial A C(F)}{\partial F}>0$.

For $\mathrm{F}>\mathrm{I}, p^{*}(F)=0$ and the agency costs of debt are constant. Q.E.D.

Results for the model with renegotiation in section IV .C: Equation (15) presents the condition for the entrepreneur to invest in the risky project. The impact of renegotiation depends on the incentives faced by the entrepreneur in the model without renegotiation, presented in section II.B. For $L<F<L+G_{L}$ the entrepreneur faced risk-avoidance incentives in the model without renegotiation. In the present setting the following al ternatives occur:

If $R>G_{L}$ there is no renegotiation. The value of the growth opportunities is lower than the renegotiation costs. Renegotiation is too costly to solve the risk-avoidance problem. If the firm defaults on its debt payment it is liquidated.

If $F+R>L+G_{L}$ and $R \leq G_{L}$ there is renegotiation but the firm's debt will not be repaid in full. Debtors benefit from allowing the entrepreneur to appropriate an amount $\varepsilon$ from the firm's future cash-flows to induce her to keep running the firm. The entrepreneur's optimal investment policy is defined below in equation (A.4). 
If $F+R \leq L+G_{L}$, which implies $R<G_{L}$, there is renegotiation and the firm's debt will be paid in full. In this case equation (15) becomes:

$$
p\left(H+G_{H}-F\right)+\alpha(1-p)\left(L+G_{L}-R-F\right) \geq I+G_{I}-F
$$

The entrepreneur will then invest in the risky project $A$ for all values of $p$ such that:

$$
p \geq p_{G}^{R}=\frac{I+G_{I}-F-\alpha\left(L+G_{L}-R-F\right)}{H+G_{H}-F-\alpha\left(L+G_{L}-R-F\right)}
$$

$p_{G}^{R}$ can be written as:

$$
p_{G}^{R}=\frac{I+G_{I}-F-\alpha\left(L+G_{L}-F-R\right)}{H+G_{H}-F-\alpha\left(L+G_{L}-F-R\right)}=\frac{I+G_{I}-L-G_{L}-(\boldsymbol{1}-\alpha)(\boldsymbol{F}-\boldsymbol{L})+(\mathbf{1}-\alpha) \boldsymbol{G}_{\boldsymbol{L}}+\alpha \boldsymbol{R}}{H+G_{H}-L-G_{L}-(\boldsymbol{1}-\alpha)(\boldsymbol{F}-\boldsymbol{L})+(\boldsymbol{1}-\alpha) \boldsymbol{G}_{\boldsymbol{L}}+\alpha \boldsymbol{R}}
$$

Equation (A.3) highlights the differences between $p_{G}^{O}$ and $p_{G}^{R}$. With probability $(1-\alpha)$ there is no renegotiation and, if state $L$ occurs, the entrepreneur loses $G_{L}$, which, in this case, is higher than $\mathrm{F}-\mathrm{L}$, the value of limited liability. With probability $\alpha$ the value of $G_{L}$ is public information and there is renegotiation at a cost $R$, allowing the entrepreneur to realize the value of the firm's growth opportunities.

By comparing (A.3) with (8) it is clear that $p_{G}^{O} \leq p_{G}^{R} \leq p_{G}^{F}$. In one limiting case, if renegotiation occurs with certainty and if it is costless (if $\alpha=1$ and $R=0$ ) then $p_{G}^{R}=p_{G}^{O}$ : there is no risk-avoidance and the entrepreneur's optimal policy is the same of an all-equity firm. In another limiting case, if renegotiation never occurs (if $\alpha=0$ ) then $p_{G}^{R}=p_{G}^{F}$ and the results from section II.B apply. In general, there is risk-avoidance even with renegotiation but, if $\mathrm{R}$ is small, there is less risk-avoidance than without renegotiation. The lower the probability $\alpha$ and the higher the cost $\mathrm{R}$, the higher are the risk-avoidance incentives. For firms with very valuable $G_{\llcorner}$even a small probability of failure in renegotiation can create large risk-avoidance incentives.

If $F>L+G L$ the entrepreneur faced risk-shifting incentives in section II's model without renegotiation. In the present setting if $R \leq G_{L}$ then there is renegotiation but the firm's debt will not be repaid in full as $G_{L}$ is not high enough. Debtors offer the entrepreneur an amount $\varepsilon$ from the firm's future cash flows to induce her to keep running the firm and to realize its growth opportunities. In this case equation (15) becomes equal to $p\left(H+G_{H}-F\right)+\alpha(1-p) \varepsilon \geq I+G_{I}-F$. This is equivalent to invest in the risky project A for all values of $\mathrm{p}$ such that: 


$$
p \geq p_{G}^{\varepsilon}=\frac{I+G_{I}-F-\alpha \varepsilon}{H+G_{H}-F-\alpha \varepsilon}
$$

$p_{G}^{\varepsilon}$ can be rewritten as:

$$
p_{G}^{\varepsilon}=\frac{I+G_{I}-F-\alpha \varepsilon}{H+G_{H}-F-\alpha \varepsilon}=\frac{I+G_{I}-L-G_{L}-(\boldsymbol{F}-\boldsymbol{L})+\boldsymbol{G}_{\mathbf{L}}+\alpha \varepsilon}{H+G_{H}-L-G_{L}-(\boldsymbol{F}-\boldsymbol{L})+\boldsymbol{G}_{\mathbf{L}}+\alpha \varepsilon}
$$

which, comparing with (8), shows that $p_{G}^{\varepsilon} \leq p_{G}^{F}$. Renegotiation increases the entrepreneur's incentives to risk-shift by subtracting the term $\alpha \varepsilon$ from the numerator and the denominator of $p_{G}^{F}$. Renegotiation increases the entrepreneur's expected value associated with the risky investment, so it increases the attractiveness of the risky project. If at time 1 the entrepreneur anticipates that debt will be renegotiated at time 2 , then her risk-shifting incentives will increase. 


\section{References}

Acharya, Sankarshan, 1996, “Charter Value, Minimum Bank Capital Requirement and Deposit Insurance Pricing in Equilibrium", Journal of Banking and Finance 20, 351-375.

Black, Fisher and M. Scholes, 1973, "The Pricing of Options and Corporate Liabilities", Journal of Political Economy 81, 637-659.

Black, Fisher and J. Cox, 1976, “Valuing Corporate Securities: Some Effects of Bond Indenture Provisions", Journal of Finance 31, 351-367.

Bolton, Patrick and David S. Scharfstein, 1990, “A Theory of Predation Based on Agency Problems in Financial Contracting", American Economic Review 106, 93-106.

Brealey, Richard A. and Stewart C. Myers, 1996, "Principles of Corporate Finance", McGraw-Hill, New York.

Chen, Yehning, J. Fred Weston and Edward I. Altman, 1995, “Financial Distress and Restructuring Models", Financial Management 24, Summer, 57-75.

Diamond, Douglas W., 1984, “Financial Intermediation and Delegated Monitoring”, Review of Economic Studies 51, 393-414.

Diamond, Douglas W., 1991, "Debt Maturity Structure and Liquidity Risk", Quarterly Journal of Economics 106, 709-737.

Fluck, Zsuzsanna, 1997, “Control Rights and Maturity: The Design of Debt, Equity and Convertible Securities", working paper, New York University.

Fluck, Zsuzsanna, 1998, “Optimal Financial Contracting: Debt versus Outside Equity", Review of Financial Studies 11, 383-418.

Furlong, Frederick T. and Michael C. Kelley, 1987, "Bank Capital Regulation and Asset Risk", Economic Review, Federal Reserve Bank of San Francisco, Spring, 20-40.

Furlong, Frederick T. and Michael C. Kelley, 1989, “Bank Capital Regulation and Risk Taking: A N ote", J ournal of Banking and Finance 13, 883-891.

Gale, Douglas and Martin Hellwig, 1985, “Incentive-Compatible Debt Contracts: The One-Period Problem", Review of Economic Studies 52, 647-663.

Geske, R., 1977, “The Valuation of Corporate Liabilities as Compound Options”, Journal of Financial and Quantitative Analysis 12, 541-552.

Green, Richard C., 1984, “Investment Incentives, Debt, and Warrants”, Journal of Financial Economics 13, 115-136.

Harris, Milton and Artur Raviv, 1988, “Corporate Control Contests and Capital Structure”, Journal of Financial Economics 20, 55-86.

Harris, Milton and Artur Raviv, 1991, "The Theory of Capital Structure", Journal of Finance 46, 297-355. 
Hart, Oliver and John H. Moore, 1989, “Default and Renegotiation: A Dynamic Model of Debt", mimeo, MIT.

Herring, Richard J. and Prashant Vankudre, 1987, “Growth Opportunities and Risk-Taking by Financial Intermediaries", J ournal of Finance 42, 583-599.

Jensen, Michael C., 1986, "Agency Costs of Free Cash Flow. Corporate Finance and Takeovers" , A merican Economic Review 76, 323-329.

Jensen, Michael C. and William H. Meckling, 1976, "Theory of the Firm: Managerial Behavior, Agency Costs and Ownership Structure", Journal of Financial Economics 3, 305-360.

John, Kose, 1987, “Risk-Shifting Incentives and Signalling Through Corporate Capital Structure", Journal of Finance 42, 623-641.

John, Kose and David C. Nachman, 1985, "Risky Debt, Investment Incentives, and Reputation in a Sequential Equilibrium", J ournal of Finance 40, 863-878.

John, Teresa A. and Kose John, 1993, “Top-Management Compensation and Capital Structure", Journal of Finance 48, 949-974.

Keeley, Michael C., 1990, “ Deposit Insurance, Risk and Market Power in Banking” , A merican Economic Review 80, 1183-1200.

Kim, E. Han, 1989, “Optimal Capital Structure in Miller's Equilibrium”, in "Financial Markets and Incomplete Information: Frontiers of Modern Financial Theory", Volume 2, 36-48, edited by Sudipto Bhattacharya and George M. Constantinides, Rowman and Littlefield.

Lang, Larry, Eli Ofek and René M. Stulz, 1996, “Leverage, Investment, and Firm Growth", Journal of Financial Economics 40, 3-29.

Myers, Stewart C., 1977, "Determinants of Corporate Borrowing", Journal of Financial Economics 5, 147-175.

Parrino, Robert and Michael S. Weisbach, 1997, “On the Magnitude of StockholderBondholder Conflicts", working paper.

Rajan, R. G., 1992, “Insiders and Outsi ders: the Choice between Informed and A rm's-Length Debt", Journal of Finance 47, 1367-1400.

Ross, Stephen A., 1977, “The Determination of Financial Structure: the Incentive-Signalling A pproach", The Bell Journal of Economics 8, 23-40.

Stulz, Rene, 1990, “Managerial Discretion and Capital Structure”, Journal of Financial Economics 26, 3-28.

Townsend, Robert M., 1979, "Optimal Contracts and Competitive Markets with Costly State Verification", Journal of Economic Theory 21, 265-293. 


\section{Figure 1}

The entrepreneur's risk choices in the classic risk-shifting framework

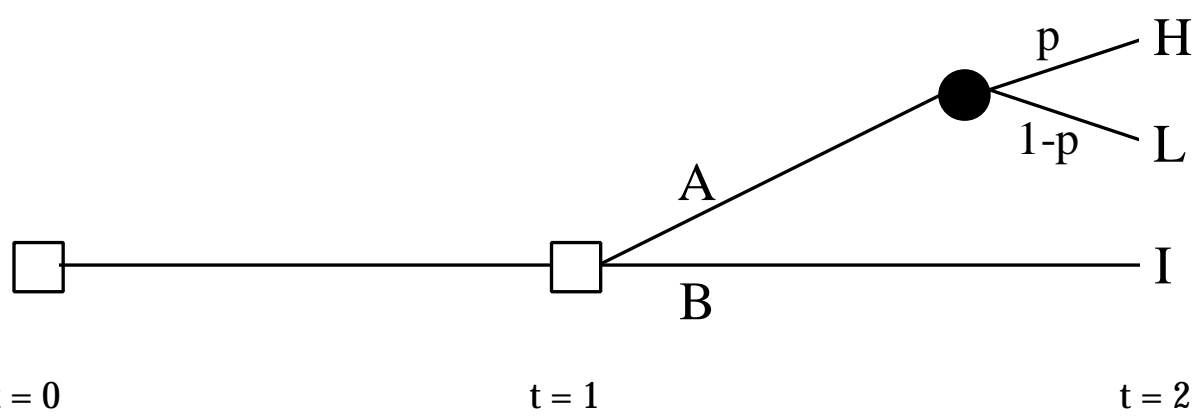

The entrepreneur issues The entrepreneur sees $p$ and Final cash-flows debt of face value $F$ makes the investment decision are realized

A : Risky project.

B: Riskless project.

$\mathrm{p}$ represents the probability that the cash-flow $\mathrm{H}$ will occur. The entrepreneur has private information, at time 1 and time 2 , concerning the value of $p$. 


\section{Figure 2}

The entrepreneur's risk choices with illiquid growth opportunities

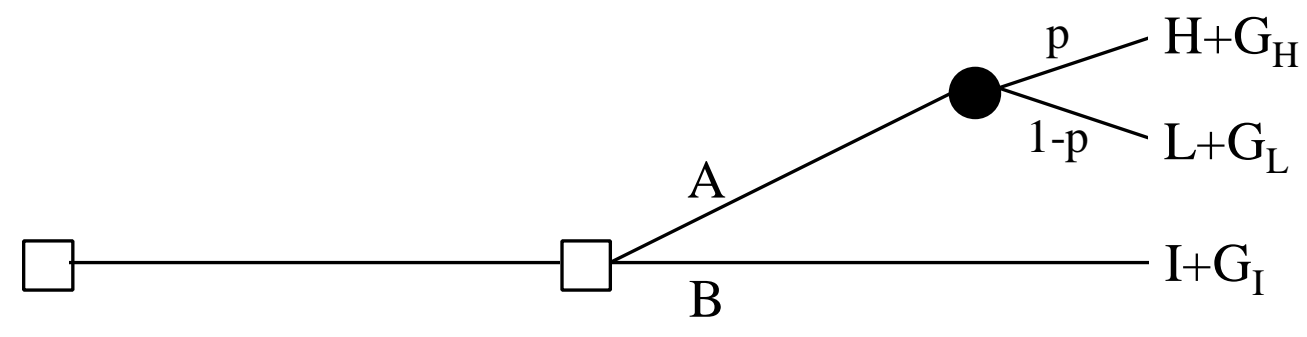

$\mathrm{t}=0$

The entrepreneur issues debt of face value $F$
The entrepreneur sees $p$ and makes the investment decision

$$
\mathrm{t}=2
$$

Final cash-flows are realized, growth opport. are not realized

\section{A : Risky project. \\ B: Riskless project.}

$p$ represents the probability that the cash-flow $H$ will occur. $G_{H}, G_{L}$, and $G_{I}$ represent the net present value of future growth opportunities. The entrepreneur has private information, at time 1 and time 2 , concerning the value of $p, G_{H}, G_{L}$, and $G_{1}$. 
Figure 3

Option analogies and Corporate Finance models

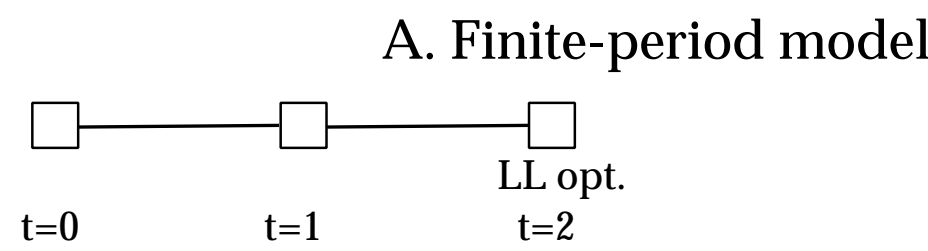

B. Finite-period model with growth opportunities

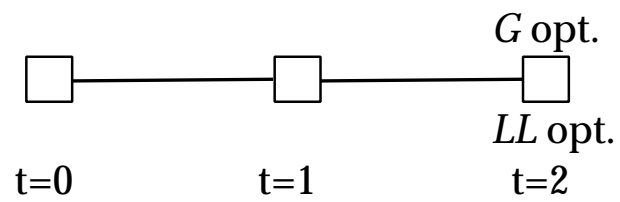

C. Multiperiod model

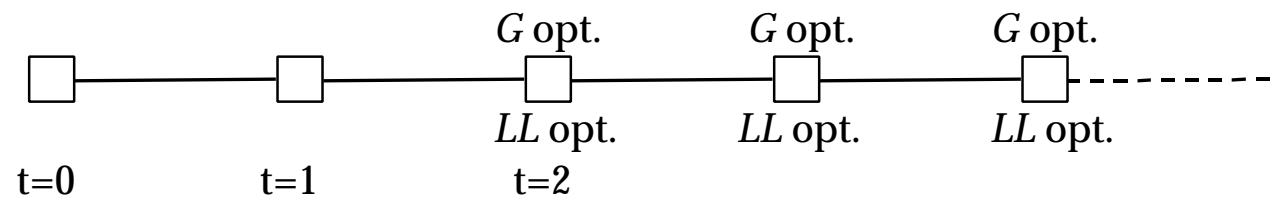

G opt. represents a growth opportunity call option; LL opt. represents a limited liability put option associated with bankruptcy 


\section{Figure 4}

\section{Illiquid growth opportunities and the entrepreneur's risk choices}
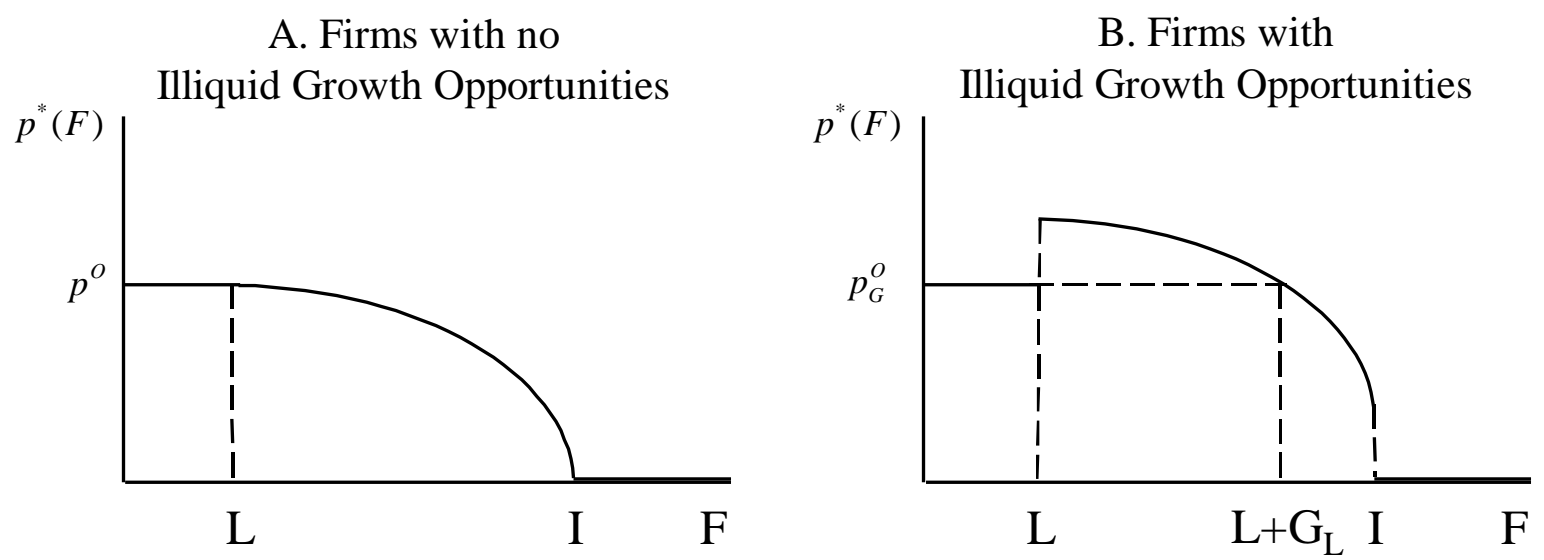

The optimal investment policies, for different debt levels, F, for firms with no illiquid growth opportunities and for firms with illiquid growth opportunities. ${ }^{15}$

\footnotetext{
${ }^{15}$ Figure 4.B assumes that $I>L+G_{L}$. If instead it was $I \leq L+G_{L}$ the figure would be similar but the firm would present risk-avoidance incentives for all values of $F$ in the interval $[L, I]$. The optimal cut-off level $p^{*}(F)$ would be always above $p_{G}^{o}$ in this interval.
} 


\section{Figure 5}

\section{Illiquid growth opportunities and the agency costs of debt}

A. Firms with no

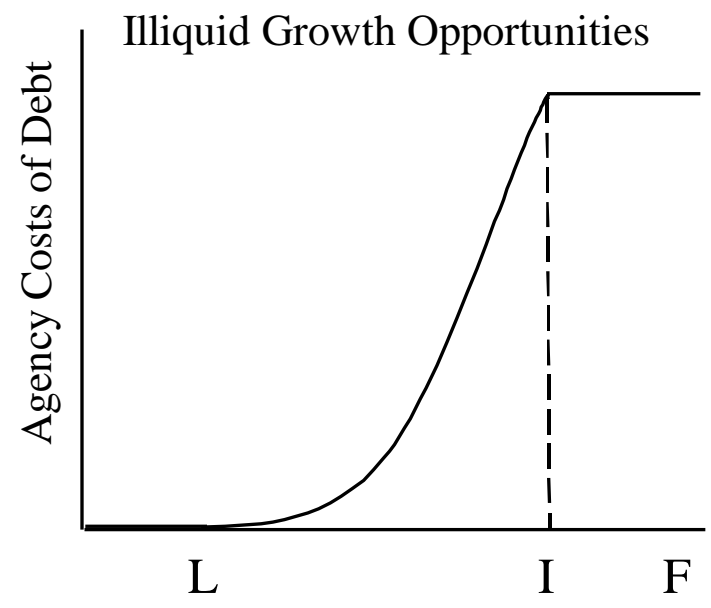

B. Firms with

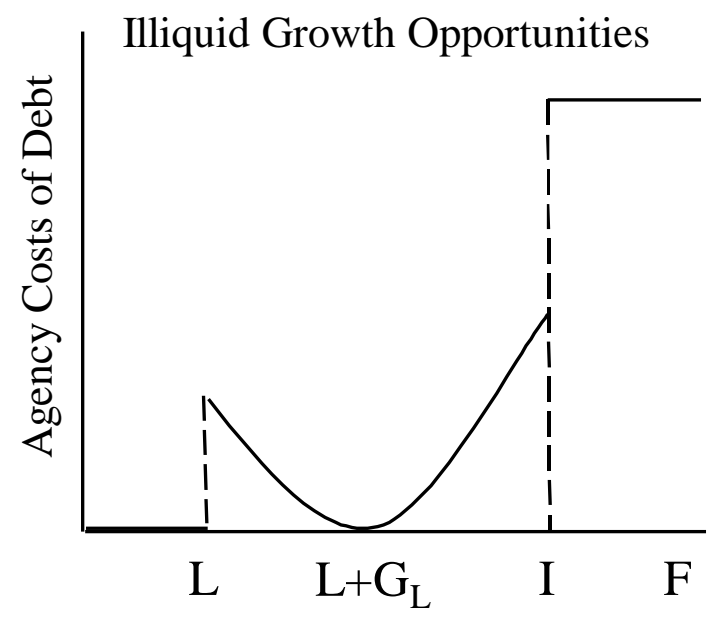

The patterns of agency costs of debt, for different debt levels, for firms with no illiquid growth opportunities and for firms with illiquid growth opportunities. ${ }^{16}$

\footnotetext{
${ }^{16}$ Figure 5.B assumes that $I>L+G_{L}$. If instead it was $I \leq L+G_{L}$ the figure would be similar but the agency costs of debt would be strictly decreasing in the interval $[L, I]$.
} 


\section{Figure 6}

\section{M yers' underinvestment problem with illiquid growth opportunities}

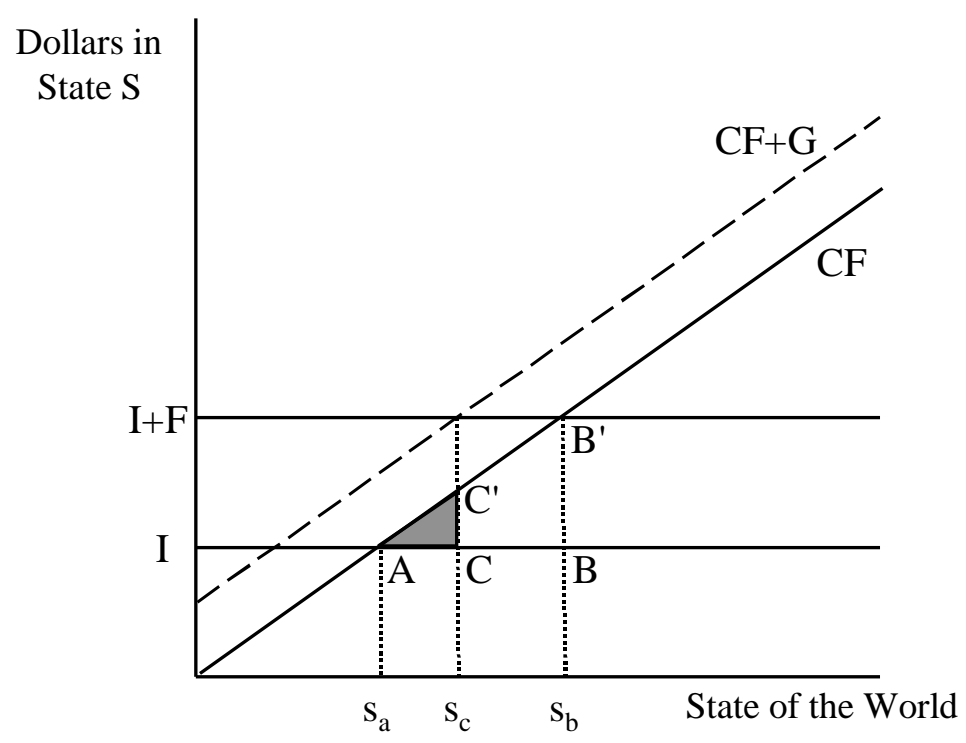

The entrepreneur's investment decision as a function of the state of the world for a firm with illiquid growth opportunities. 


\section{Figure 6.A}

\section{Myers' underinvestment problem and illiquid growth opportunities}
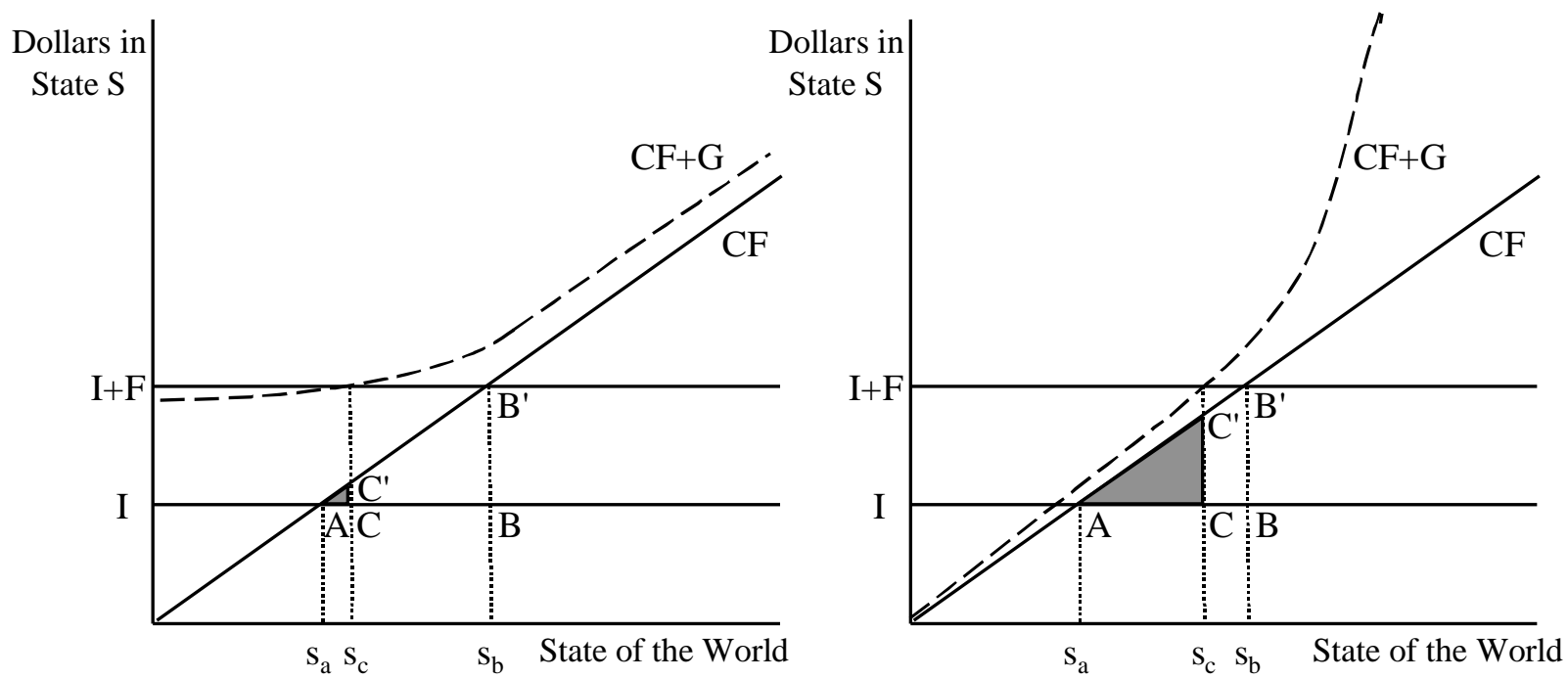

The entrepreneur's investment decision as a function of the state of the world for firms with illiquid growth opportunities. The value of the growth opportunities varies across states of nature. The dimension of Myers' underinvestment problem depends on the correlation between the value of the illiquid growth opportunities and the level of the project's cash-flows. 
Figure 7

The entrepreneur's investment decision with illiquid growth opportunities

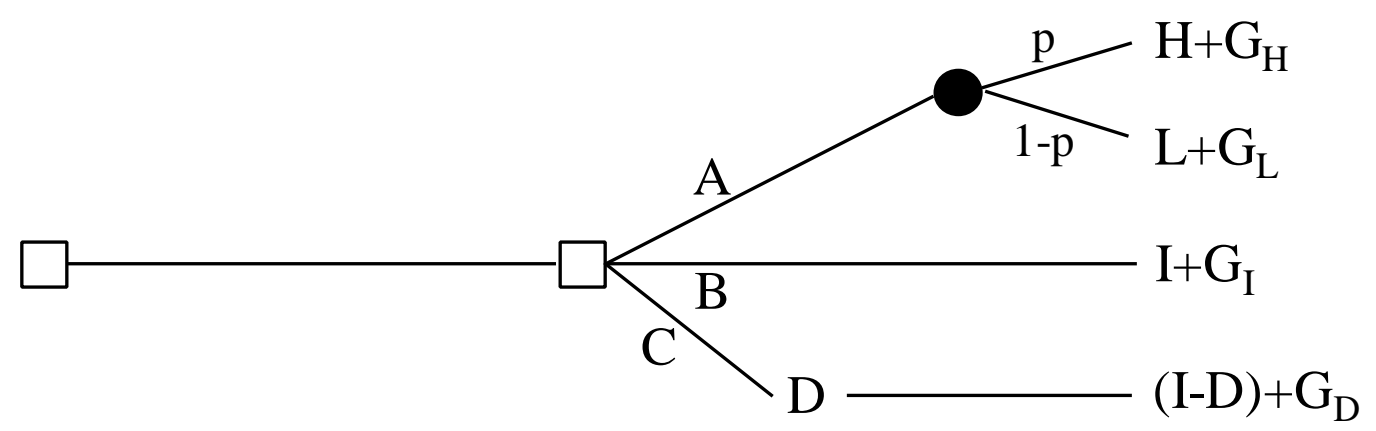

$t=0$

The entrepreneur issues debt of face value $F$

$$
\mathrm{t}=1
$$

The entrepreneur sees $p$ and makes the investment decision

$$
\mathrm{t}=2
$$

Final cash-flows are realized, growth opport. are not realized
A : Risky project.
$B$ : Riskless project.
$C$ : Payment of a dividend $D$.

p represents the probability that the cash-flow $H$ will occur. $G_{H}, G_{L}, G_{I}$ and $G_{D}$ represent the net present value of future growth opportunities. The entrepreneur has private information, at time 1 and time 2 , concerning the value of $p, G_{H}, G_{L}, G_{I}$ and $G_{D}$. 
